EUROPEAN CENTRAL BANK

WORKING PAPER SERIES

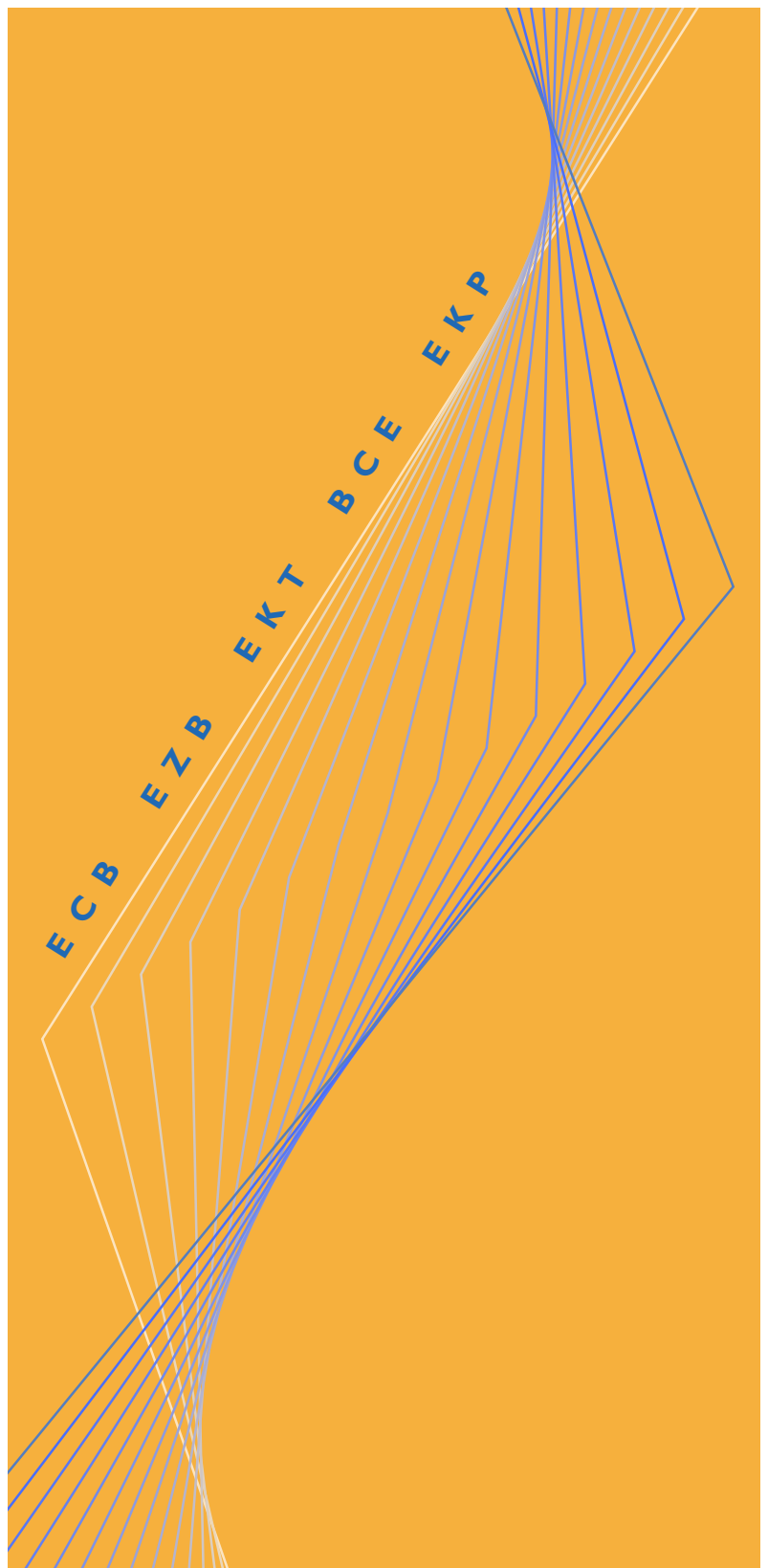

WORKING PAPER NO. I 4 I

ASSET PRICES AND FISCAL

BALANCES

BY FELIX ESCHENBACH AND

LUDGER SCHUKNECHT

May 2002 


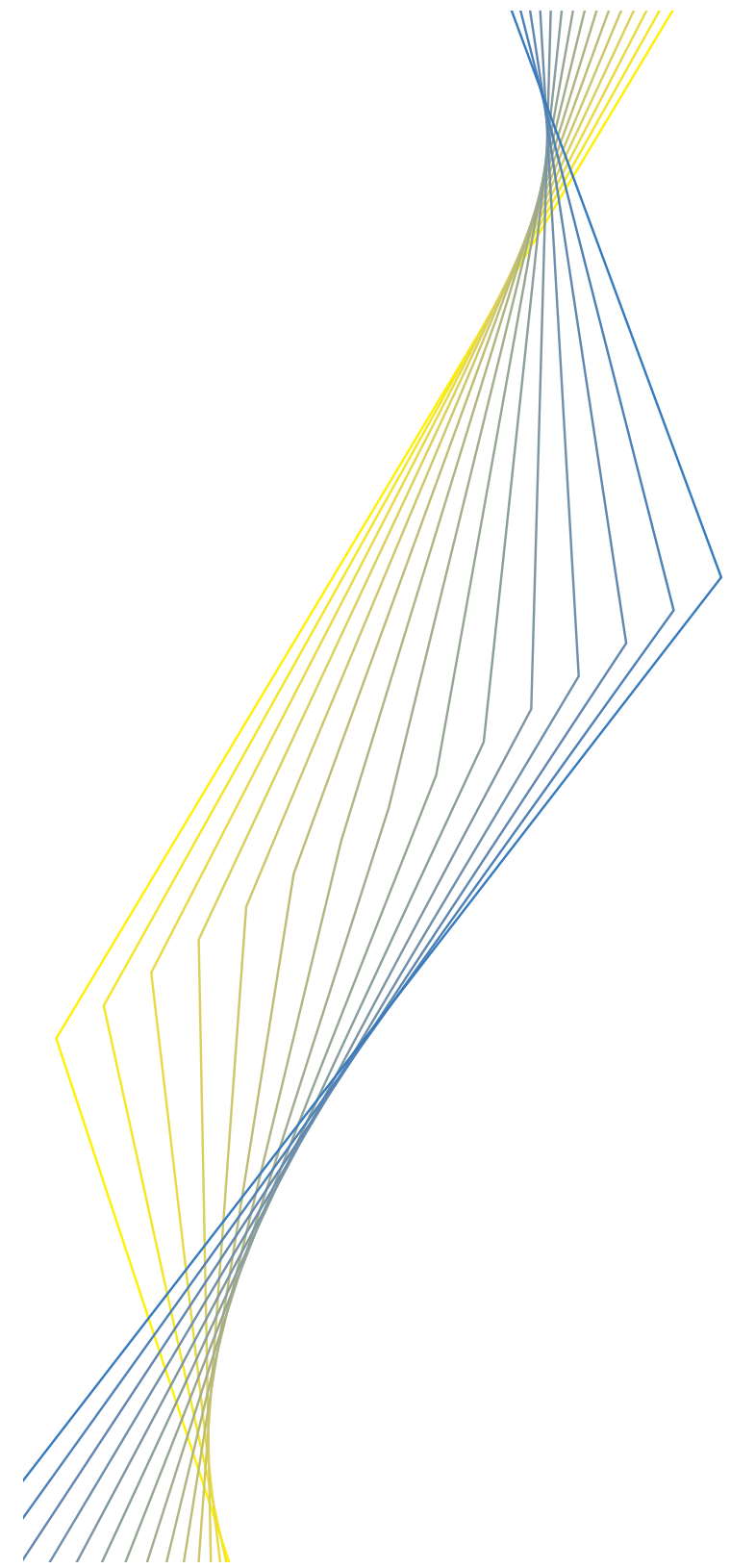

WORKING PAPER NO. I 4 I

\title{
ASSET PRICES AND FISCAL
} BALANCES

\section{BY FELIX ESCHENBACH AND LUDGER SCHUKNECHT*}

\author{
May 2002
}


(C) European Central Bank, 2002

\begin{tabular}{|c|c|}
\hline \multirow[t]{2}{*}{ Address } & Kaiserstrasse 29 \\
\hline & D-603 I I Frankfurt am Main \\
\hline & Germany \\
\hline \multirow[t]{3}{*}{ Postal address } & Postfach 160319 \\
\hline & D-60066 Frankfurt am Main \\
\hline & Germany \\
\hline Telephone & +496913440 \\
\hline Internet & http://www.ecb.int \\
\hline Fax & +496913446000 \\
\hline Telex & 4 I I I44 ecb d \\
\hline
\end{tabular}

Reproduction for educational and non-commercial purposes is permitted provided that the source is acknowledged.

The views expressed in this paper are those of the authors and do not necessarily reflect those of the European Central Bank.

ISSN $156 \mid-0810$ 


\section{Contents}

$\begin{array}{lr}\text { Abstract } & 4\end{array}$

Asset Prices and Fiscal Balances-A Non-Technical Summary $\quad 5$

$\begin{array}{llr}\text { I Introduction } & 7\end{array}$

2 The relations between public finances and asset prices $\quad 8$

3 An econometric study of links between asset prices and fiscal variables $\quad 15$

$\begin{array}{llr}4 \text { Results } & 19\end{array}$

5 Conclusions $r 25$

$\begin{array}{lr}\text { Bibliography } & 28\end{array}$

$\begin{array}{lr}\text { Tables and Charts } & 39\end{array}$

$\begin{array}{ll}\text { European Central Bank Working Paper Series } & 39\end{array}$ 


\begin{abstract}
The paper argues that there are important links between asset prices and public finances which can strongly affect the variability of fiscal balances. Asset prices affect fiscal balances via capital gains and turnover related taxes, and via wealth effects on consumption and indirect taxes. The fiscal costs of asset price changes can be higher if government can be held liable for balance sheet losses from an asset price downturn.

An empirical study finds significant effects of house and/or stock prices on revenue in a majority of the 17 OECD countries and revenue categories examined. On average, a 10-percent change in real estate and stock prices has a similar effect on the fiscal balance as a 1-percent change in output, although effects differ considerably across countries. By 2001/2002, some countries' fiscal balances seem upward biased, due to positive effects from earlier asset price booms.
\end{abstract}

JEL codes: H3, H6, E6, G1

Keywords: Fiscal policies, deficits, asset prices, revenue, fiscal institutions 


\section{Asset Prices and Fiscal Balances—A Non-Technical Summary}

The political and academic debate in recent years has given considerable attention to the short term stability and long term sustainability of public finances. This discussion has become particularly relevant in the EU since the Maastricht Treaty and the Stability and Growth Pact (SGP) have introduced targets for deficits over the cycle ("close to balance or in surplus") and ceilings on deficits and debt ( 3 and 60 percent of GDP, respectively). Fiscal effects from automatic stabilisers over the business cycle, high debt and population aging, are argued to justify the "close to balance or in surplus" requirement of the Stability and Growth Pact. The latter provides a "safety margins" in budgetary positions so that the deficit limit is "normally" not breached even when automatic stabilisers operate over the cycle.

The main shortcoming of the debate is perhaps the omission of asset price linkages with public finances which can introduce much additional variability into countries' fiscal balances. To substantiate this claim, we first argue in this paper that fiscal policies and fiscal variables interact with asset prices. As illustrated by a simple accounting framework, the main channels from asset prices to fiscal variables are direct effects on revenue through capital gains and turnover related taxes, and indirect effects through wealth effects on consumption. Moreover, fiscal effects can rise significantly when the government can be held liable for balance sheet losses incurred during an asset price downturn.

An empirical study of the fiscal effects of real estate and stock price changes in 17 OECD countries confirms the relevance of such effects. In all countries, corporate income and capital transaction taxes are significantly affected by asset price changes and in a majority of countries this is also true for income taxes on households and indirect taxes. The overall goodness of fit of equations increases considerably when asset price variables are added, as compared to the "traditional" literature looking only at fiscal and cyclical variables.

With the findings on the elasticity of fiscal variables to asset price changes it is also possible to calculate revenue and budget sensitivities. We find that in all countries, there is some risk of more variability in fiscal balances due to asset price changes but this risk differs considerably across countries. On average the budget sensitivity of a $10 \%$ asset price change is similar to a $1 \%$ output change. Moreover, as of 2001/2002, the study finds an upward bias in fiscal balances in a number of countries that experienced asset price booms in the late 1990s. It suggests that a number of countries' fiscal positions are vulnerable to asset price changes and reversals. 
While asset price developments can give rise to significant fiscal effects, the impact on economic stability is not clear. On the one hand, asset prices and growth tend to be correlated (albeit less on a year to year basis) so that the revenue effects may work counter-cyclically. However, revenue effects are often lagged so that a dampening/stimulating effect on demand and corporate financial positions continues well into asset price and (if correlated) conjunctural downturns/upswings. Governments may also countervail the stabilising effect via discretionary tax or expenditure measures.

As to policy implications, the findings suggest to be cautious when attributing improvements in the fiscal balance beyond normal cyclical effects to structural factors. If asset price related, such factors might prove to be temporary. Moreover, when the additional revenue is treated as permanent by policy makers, it can result in an increase of expenditure commitments or tax cuts. Fiscal effects from asset price changes are the result of the prevailing fiscal institutions. Governments can assess and if necessary reform its fiscal system in light of its interaction with asset prices. Care should be taken, however, that fiscal reform does not exacerbate the volatility of asset prices and thereby fiscal implications. Finally, governments with fiscal variables sensitive to asset prices and which observe strong asset price increases might consider adjusting their budgetary safety margin to be prepared for the fiscal costs of an eventual downturn. 


\section{Introduction}

The political and academic debate in recent years has given considerable attention to the short term stability and long term sustainability of public finances. This discussion has become particularly relevant in the EU since the Maastricht Treaty and the Stability and Growth Pact (SGP) have introduced targets for deficits over the cycle ("close to balance or in surplus") and ceilings on deficits and debt (3 and 60 percent of GDP, respectively). Fiscal effects from automatic stabilisers over the business cycle, high debt and population aging, are argued to justify the "close to balance or in surplus" requirement of the Stability and Growth Pact. The latter provides a "safety margins" in budgetary positions so that the deficit limit is "normally" not breached even when automatic stabilisers operate over the cycle.

Much work has focused on fiscal effects arising from the budget sensitivity to output changes due to automatic stabilisers (van den Noord, 2000; Bouthevillain et al, 2001), the future costs of population aging under various economic and policy scenarios (Rother, Catenaro and Schwab, 2002; McMorrow \& Roeger, 2002; Hagemann \& Nicoletti, 1998), and an excessive debt level (Buiter, 1989). The size of the budget sensitivity, the debt and the future ageing-related costs determines the necessary ambitiousness of countries' fiscal position to prevent a breach of the deficit and debt levels in the future. But these considerations and resulting calculations may underestimate the required safety margins if they have not focussed on all the major relevant factors that can strongly affect fiscal balances.

To our mind, the main shortcoming of the debate is the omission of asset price linkages with public

finances. ${ }^{1}$ The study, therefore, has two main objectives. First, we will discuss the interrelationship between asset prices and public finances. Fiscal policies can affect asset prices via the tax/subsidy system and via discretionary fiscal policies. Of more concern for this study is the claim that asset price changes can have significant effects on fiscal variables via revenue channels, i.e. capital gains taxes, wealth effects on consumption and asset turnover taxes. In addition we discuss the fiscal costs from a government takeover of balance sheet losses. While these links are in principle well known, systematic studies are so far absent.

Secondly, we conduct an econometric investigation of asset price effects on a number of tax revenue categories for 17 OECD countries. We show that various revenue categories are indeed 
significantly affected by asset price changes in many countries. We also calculate related elasticities of budget variables to asset price changes. Revenue effects from a 10 percent asset price change average $0.4 \%$ of GDP but vary significantly between 0.1 and $0.8 \%$ of GDP. Fiscal effects can hence be very important in some countries when asset prices rise or fall strongly. They can be stabilising when asset price changes coincide with the business cycle but lagged effects and political economy reasons raise doubts about this. Finally, we find that some countries that experienced strong real estate booms in recent years may report fiscal positions that are embellished by these booms and that could be vulnerable to asset price reversals. However, in this study we do not look in detail at the implications of asset price adjustments on financial stability and the fiscal costs of bank and enterprises recapitalisation. These typically affect fiscal balances via expenditure or government financial activities (rather than revenue) and are subject to more detailed analysis in Eschenbach and Schuknecht (2002).

Nevertheless, even without the more dramatic effects of financial instability, this study suggests that asset price related fiscal effects can strongly alter fiscal positions and jeopardize short term fiscal targets. This risk is particularly large for countries where fiscal variables are sensitive to asset price changes and where asset prices have proven very volatile.

The next section of the study discusses the interaction between asset prices and fiscal policies, develops a simple accounting framework and on that basis derives testable hypotheses. Sections three and four contain an econometric analysis and its results. The concluding section summarises and discusses some policy implications.

\section{The relations between public finances and asset prices}

As mentioned, there is by now an important literature that examines the effects of economic fluctuations on fiscal variables and the budget balance. This literature looks at economic flow variables, such as output or foreign demand, when assessing fiscal elasticities to economic shocks, and when subsequently deriving sensitivity measures of the budget to economic fluctuations. This paper builds on and extends this analysis by looking at the interaction between asset prices and fiscal policies.

The relationship between asset prices and public finances goes in both directions. We first briefly discuss some channels via which fiscal policies can affect asset prices before turning to a more thorough

\footnotetext{
${ }^{1}$ An exception to this rather narrow focus of the "conventional" debate is the pioneering study by Hemming and
} 
analysis of the effects of asset price changes on fiscal variables. Two of the most important assets from an economic perspective that also have a fiscal bearing are real estate and stocks, and the analysis in the paper is limited to these.

\section{A. Fiscal policies affect asset prices via the tax/subsidy regime, discretionary policies and via the availability of government bailouts}

The first important channel by which fiscal policies affect asset prices is via the tax and subsidy system. The latter influences asset prices mainly through their effect on after tax/subsidy rates of return. ${ }^{2}$ Increases in capital gains taxes reduce the after tax return and, thereby, the market value of assets. Turnover taxes can affect asset prices directly or indirectly (e.g. through their effect on market liquidity). Subsidising asset acquisition and ownership raises the after tax return of assets which, in turn, is likely raise their price. For example, mortgage interest deductibility or price-related subsidies for house purchases increase people's willingness to pay for houses. Furthermore, quasi-fiscal, regulatory policies (for example, pension fund regulation, zoning regulation and "speculation"-related policies) can affect supply and demand in asset markets.

It is also important to note that discretionary policy changes can induce asset price changes. For example, if a country raises the deductibility of mortgage interest, this lowers the after tax interest rate for purchasing the asset on credit. This, in turn, raises the expected value of the asset and is likely to contribute to price increases.

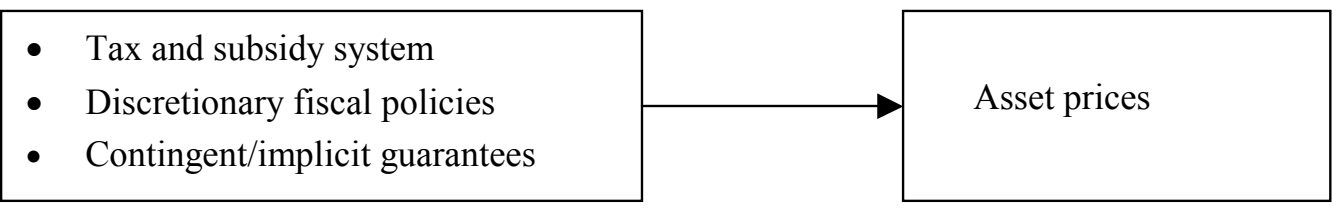

The timing of such discretionary policy changes is important when it comes to determine whether fiscal policies exacerbate asset price swings or moderate them. Conceptually, this is analogous to the debate offiscal policy effects on the cyclicality of output. A reduction of mortgage tax credits at the beginning or during a downturn in house prices can raise the magnitude of the downturn. Capital gains tax changes which raise the time period required to be exempted from such taxes, can reduce temporarily the

Petrie (2000) which discusses fiscal vulnerability from various angles, including to some extent those at the heart of this study.

${ }^{2}$ See, for example, Jonung and Stymne (1997) for such influences in Sweden in the later 1980s/early 1990s. 
supply of such assets. If this happens during an upswing of asset prices, this measure could raise prices further. Similarly, the abolition of capital gains taxes on the sale of shares during a boom phase is likely to magnify the boom. ${ }^{3}$

A further channel by which fiscal policies can affect asset prices relates to the rules for government bailouts of the private sector. If private agents anticipate an (implicit or explicit) government guarantee for balance sheet losses, the anticipation of government bailouts can result in less prudent behaviour (moral hazard) by banks and investors and more volatile asset prices. The latter, in turn, raises the probability that a government bailout is needed. Whether such moral hazard problems exist, however, depends very much on countries' rules for corporate governance and government bailouts. ${ }^{4}$

\section{B. Asset prices and their effect on fiscal variables}

As mentioned above, asset prices have not played a prominent role in the analysis of the determinants of fiscal variables and balances. We argue that asset prices affect fiscal variables directly through two channels. ${ }^{5}$ The first channel works through fiscal revenue. It reflects the "orderly" reaction of fiscal variables to changes in asset prices (and financial sector balances) as determined by the existing fiscal/tax rules and institutions. The second channel relates to situations of government bailouts which are often conducted in a more ad hoc manner, and which are not necessarily fully reflected in government budgets.

As to the first channel, asset price changes are likely to affect capital gain/loss-related taxes. These are typically recorded as part of direct taxes on households and corporations. Much, however, depends on the prevailing tax system. Personal income taxes may be affected in four ways: if the capital gains from private asset sales are taxed, if asset price effects on profits and dividends feed into personal income taxes, if (taxable) rental income changes with asset prices, and if interest payments (e.g. on

\footnotetext{
${ }^{3}$ Fiscal policy changes can also moderate asset price variation but the problems with any type of discretionary fiscal policies (knowledge of position relative to cycle, implementation lags, difficulty to reverse policies) suggest caution with asset price oriented discretionary fiscal policy making.

${ }^{4}$ Gropp and Vesala (2002) argue this point very convincingly when discussing the role of deposit insurance schemes as setting clear limits for government liabilities and thereby reducing moral hazard. The importance of adequate capital, accounting rules and bank regulation and supervision in this context is frequently discussed in the literature. ${ }^{5}$ In addition, there can be second-round effects via output and government financing conditions. If an asset price increase stimulates investment and consumption, the resulting output and employment effects will further boost revenue. If asset price booms induce the government to raise interest rates, and if the government has a lot of short term debt and a large debt ratio, this may raise the government interest bill. E.g. a $1 \%$ interest rate increase on $100 \%$ of public debt of which $25 \%$ need to be refinanced within 12 months, would raise the interest bill by $0.1 \%$ in the first year and by $0.4 \%$ in the second year (see Eschenbach and Schuknecht, 2002 for a more detailed discussion).
} 
mortgages) are tax deductible. Ownership structure and dispersion (for example, a high house ownership ratio) also affects the relation between asset prices and personal income tax revenue. If the asset is an important element in household balance sheets (e.g., a significant share of wealth being held as stocks or real estate), revenue effects are also expected to be larger.

Revenue from corporate income taxes is also likely to be affected by asset price changes if related gains affect the taxable base (most strongly perhaps in the financial sector). Capital gains or losses may affect revenue immediately or with a lag, depending on tax rules and in particular whether capital gains are taxed when accrued or realised and over what time frame losses can be deducted.

Given growing internationalisation of asset holdings, fiscal variables are not only subject to domestic asset price fluctuations. A company holding assets abroad may have to pay tax on capital gains or may be able to write off losses against tax obligations at home. Financial sector balance sheets may become more vulnerable to developments abroad if a larger share of loans goes to foreigners. On the other hand, internationally well-diversified portfolios may work like an insurance and, thereby, reduce the riskyness of balance sheets, and thereby also the volatility of fiscal variables. ${ }^{6}$

Moreover, asset prices affect consumption and thereby indirect taxes via so-called wealth effects. Household and firms feel richer when the value of their assets rises, even if they do not realize the profits, and confidence is likely to be affected positively. Wealth-effects are, hence, also a form of balance sheet effect. Moreover, credit-worthiness of households and firms improves as the value of collateral rises. These effects stimulate consumption and (less importantly for immediate tax effects) investment. Countries with a broad distribution of house and stock ownership are more likely to experience such effects. Financial market institutions that enhance the ability to turn paper wealth into consumption (e.g., via home equity loans) may also boost wealth effects. Hence, we hypothesize that asset price increases are significantly correlated with private consumption and indirect tax developments due to wealth effects. As much household wealth is in real property this is likely to be the more important transmission channel in most countries. ${ }^{7}$

\footnotetext{
${ }^{6}$ Wealth taxes are also related to this channel although they are typically not recorded under direct taxes and their importance has declined in many countries in recent years. An exception is perhaps local property taxes. They sometimes depend on the value of the real estate and may, thereby, work like a tax on wealth including accrued real estate capital gains.

${ }^{7}$ Recent literature has given more attention to wealth effects across assets and countries. See, for example, Case, Quigley and Shiller, 2001; Lettau and Ludvigson, 2001; or Ludwig and Slok, 2002.
} 
Governments also often draw revenue from transactions in assets, in the form of turnover taxes. These taxes are important especially regarding real estate transactions and can reach a noticeable share of total revenue. To our knowledge, there is no industrial country that does not tax real estate transactions while many countries have abolished stock turnover taxes in recent years.

Fourthly, balance sheet deterioration can turn into a government liability via a government bailout. If asset price declines take on major proportions and are coupled with corporate and/or financial sector difficulties, significant additional fiscal costs to the government can arise from helping out insolvent companies and banks. If an asset price fall results in difficulties for the corporate sector, the government may be burdened by called-up guarantees on loans. If the industry is important for political reasons (say as an important regional employer), the government may also be inclined to provide subsidies or other types of emergency assistance. More importantly, the government may have implicit or explicit contingent liabilities in the financial system, where non-performing loans due to asset price declines may bring down banks and induce government support.

Conceptually such bailouts are equivalent to a capital gains tax (which as a mirror image implies the deductability of losses from tax obligations). A full loss-takeover by government is equivalent to a tax rate of $100 \%$. Such obligations can be very important in quantitative terms (Caprio and Klingebiel, 1996). However, bailouts are likely to affect public finances through other channels than revenues. They are often financed in an ad hoc manner through budgetary subsidies or government financial activities. The latter could take the form of equity injections or the purchase of bad loans via a holding company which after completion of its task is liquidated with the government footing the bill. This latter method would augment the debt but not necessarily affect the budget deficit. Moreover, the effect of bailouts on revenue is uncertain. They may re-establish a company's ability to pay taxes more quickly than a scenario when losses have to feed fully through corporate balance sheets, thereby possibly depressing receipts even well after the losses were incurred.

\section{A simple accounting framework}

The implications of asset price/valuation changes on fiscal variables described above can be illustrated in a very simple accounting framework with two sectors, private and government. ${ }^{8}$ There are

\footnotetext{
${ }^{8}$ There are many simplifying assumptions underlying this framework, including for example the current account balance corresponding to the savings-investment balance (hence no capital transfers).
} 
four types of taxes $t_{y}$, levied on income $Y$, $t_{c}$ levied on consumption $c_{y} Y, t_{w}$ levied on capital gains $w$, and $t_{t}$ levied on capital/wealth turnover $\quad w$. There are no collection lags. Assets/wealth are only held by the private sector. Private and public sector savings including links to asset prices/changes in wealth are illustrated in equations 1) and 2).

\section{$\underline{\text { Savings }}$}

1) $S_{p}=\left(1-t_{y}\right) Y-\left(1+t_{c}\right)\left(c_{y} Y+c_{w}\left(1-t_{w}\right) \Delta w\right)-t_{w} \Delta w-t_{t} \sigma w$

2) $S_{g}=t_{y} Y+t_{c}\left(c_{y} Y+c_{w}\left(1-t_{w}\right) \Delta w\right)+t_{w} \Delta w+t_{t} \sigma w-C_{g}$

Changes in private and public sector financial balance sheets differ from savings due to investment and changes in (private) wealth (adjusted for taxes) (equations 3 and 4).

\section{$\underline{\text { Financial balance sheets }}$}

3) $F B_{p}=\left(1-t_{y}\right) Y-\left(1+t_{c}\right)\left(c_{y} Y+c_{w}\left(1-t_{w}\right) \Delta w\right)-t_{t} \sigma w-I_{p}+\left(1-t_{w}\right) \Delta w$

4) $\quad F B_{g}=t_{y} Y+t_{c} c_{y} Y+t_{w} \Delta w+t_{c} c_{w}\left(1-t_{w}\right) \Delta w+t_{t} \sigma w-C_{g}-I_{g}$

An increase in asset prices/asset valuation can have a negative effect on private savings if individuals consume more and have to pay capital gains taxes (5). Public sector savings would then increase but by less then the decline in private savings (6). The difference between (5) and (6) is the additional consumption due to asset price/wealth increases (wealth effects, adjusted for consumption and capital gains taxes. Assuming constant investment, this changes the economy's savings-investment/current account balance (7).

\section{Changes in savings due to asset price changes}

5) $\frac{\partial S_{p}}{\partial \Delta w}=-\left(1+t_{c}\right) c_{w}\left(1-t_{w}\right)-t_{w}-t_{t} \sigma$

6) $\frac{\partial S_{g}}{\partial \Delta w}=t_{c} c_{w}\left(1-t_{w}\right)+t_{w}+t_{t} \sigma$

7) $\frac{\partial S_{p}}{\partial \Delta w}+\frac{\partial S_{g}}{\partial \Delta w}=-c_{w}\left(1-t_{w}\right)=\Delta$ current account 
Most importantly for our analysis, we can also calculate the change in private and public sector financial balance sheets. Private sector balance sheets improve in an asset price upturn by the valuation increase adjusted for taxes and wealth effects (8). Public sector balance sheets also improve by the tax receipts from capital gains and wealth effects. This is the asset price/wealth related change in the fiscal balance (9).

\section{Changes in financial balance sheets due to asset price effects}

8) $\frac{\partial F B_{p}}{\partial \Delta w}=1-t_{w}-\left(1+t_{c}\right) c_{w}\left(1-t_{w}\right)-t_{t} \sigma$

9) $\frac{\partial F B_{g}}{\partial \Delta w}=t_{w}+t_{c} c_{w}\left(1-t_{w}\right)+t_{t} \sigma=\Delta$ fiscal balance

Tax rates $t_{\mathrm{w}}$ normally operate symmetrically during an upturn and dowturn of asset prices. Hence governments in fact finance part of private balance sheet losses if such losses can be deducted from the income tax burden. A government bailout of private sector financial losses can be illustrated by an asymmetric tax rate $t_{w}$ which takes a different value during a downturn than during an upturn. In the extreme case, where the government takes over all losses, the implicit tax rate $t_{w}$ is $100 \%$. This formalisation, though illustrative, is nevertheless rather crude as it assumes some kind of tax rule on which the bail-out is based (an "orderly" adjustment) while this is typically not the case.

Moreover, there may be important interaction effects which are not considered in this accounting framework. Tax bases (such as compensation of employees) may not only affect revenue but also asset prices so that there could be multicollinearity between the three variables. Asset price changes can affect output indirectly, e.g., via second round effects from higher consumption and investment. ${ }^{9}$

Summarising these considerations on the transmission of asset price changes to fiscal variables, three straightforward and testable hypotheses as to the interaction with direct, indirect and turnover tax revenue emerge:

1) Asset price changes are expected to significantly affect direct tax receipts from corporations and households via capital gains taxes.

${ }^{9}$ This would suggest a general equilibrium analysis. However, the fact that the full extent of asset valuation changes is difficult to explain in existing models, and asset valuation losses seem to disappear partly into "black holes" suggests caution to such an approach. See the finance literature for more details (e.g. Dai et al, 2000). 
2) Asset price changes are anticipated to affect indirect tax receipts via wealth effects on private consumption.

3) Asset price changes are likely to affect tax receipts from capital transactions.

In contrast, episodes with government bailouts in the context of financial instability do not yield such straightforward hypothesis. For these events, it would not be appropriate to look only at the effect of asset prices on revenue as this would not be the full picture of fiscal effects, but to have a more encompassing view of the effect on both budget variables and debt. As to methods, case studies (rather than econometrics) of the full fiscal effect (and not only on revenue and deficits) would seem the appropriate form of studying such events. Eschenbach and Schuknecht (2002) have endeavoured such an analysis of countries experiencing strong asset price fluctuations, financial instability and government bailout. In contrast, this study is limited to analysing the channels and magnitudes by which asset price changes affect revenue only. Note, however, that the revenue effects studied here are likely to occur during both "normal" and "crisis" times.

\section{$3 \quad$ An econometric study of links between asset prices and fiscal variables}

\section{A. General Formulation of Estimation Equations and Explanation of Variables}

In the following we conduct an econometric analysis of the relation between asset prices and fiscal revenue from direct, indirect and capital turnover taxes. We distinguish three estimation equations, based on the hypotheses on the transmission channels identified above.

\section{Model formulation}

As to the first equation, direct taxes on households and corporations are expected to be determined by their traditional tax bases, i.e., compensation of employees and gross operating surplus. In addition, we anticipate a revenue effect from asset price changes via capital gains-related taxes.

(1) direct tax revenue $=\mathrm{f}$ (compensation of employees/gross operating surplus; asset price effects on capital gains)

In the second equation, indirect taxes are determined by private consumption which, in turn, is traditionally a function of disposable income. We test this second relationship by adding asset prices as proxies for wealth effects on private consumption. 
(2) indirect tax revenue $=\mathrm{f}$ (private consumption)

private consumption $=\mathrm{f}($ disposable income, asset price related wealth effects $)$

The third equation refers to taxes on financial and capital transactions. These are exclusively determined by asset transactions:

(3) capital turnover tax-related revenue $=\mathrm{f}$ (asset prices proxying turnover)

\section{Variable selection}

In all three equations, the dependent variables and the independent variables reflecting traditional tax bases are all readily available. The latter are in fact the channels examined by the literature on the cyclical adjustment of budget balances.

The fiscally most relevant assets, as mentioned above, are stocks and real estate. However, we do not know the effect of changes in these asset prices on tax bases, i.e., the capital gains tax base, wealthinduced effects on private consumption or the base for turnover taxes, and related changes in the tax base have to be approximated. In principle, asset valuations, i.e. price times quantity, would be the best proxies. However, quantity data on real property are not available for longer time series if at all. Stock market valuation data is more readily available although time series are also rather short. We, therefore, use two asset price indicators, i.e. stock prices and real estate/property prices as proxies in the estimations. ${ }^{10}$

Finally, we include dummy variables to capture important tax reforms (e.g., the Swedish tax reforms of the early 1990s) or special events/shocks (e.g., German unification) that are likely to have significant effects on fiscal revenue. This procedure is second best to a clear account of discretionary measures and shocks and quantitative estimates of their revenue impact. Nevertheless, in the absence of such information, this is an improvement over the literature where discretionary measures are not reflected in the estimations.

Expected timing of impact from asset price variables

\footnotetext{
${ }^{10}$ From a short term fiscal perspective, price rather than valuation indices are not problematic, because quantities change much more slowly than prices. Another concern could be the comparability of asset price indicators across countries. Some indices are broader than others, so that a direct comparability is not possible. This is not of great importance here, because as discussed in more detail below, we apply time-series techniques on a country by country basis, and not panel analysis. The main criterion for the choice of index is its broad market coverage which is satisfied in all countries in our sample.
} 
The expected timing of the fiscal impact from asset price variables is also worth discussing. As regards direct taxes, we expect an immediate or a lagged positive (negative) impact from asset price increases (decrease) depending on when taxes on capital gains are typically paid. Moreover, the deductibility of mortgage interest payments from personal income tax in some countries may result in an immediate or lagged negative impact of a house price increase on fiscal revenue.

As regards wealth effects on consumption, an immediate or a lagged impact are both possible, depending on when the asset price adjustment occurred and with what lags consumers react to the increase. It is also conceivable, that the immediate impact of asset price changes is higher than the permanent one, so that a partial reversal of the impact would be found. Finally, as regards capital turnover taxes, immediate and lagged effects are possible, depending on the timing of asset price changes and collection lags.

\section{B. The Countries and the Data}

We focus on 17 industrialised OECD countries with well-developed asset markets and good data availability: Australia, Belgium, Canada, Denmark, Finland, France, Germany, Ireland, Italy, Japan, Netherlands, Norway, Spain, Sweden, Switzerland, UK and USA. Some industrialised countries had to be omitted due to poor data availability (for instance Portugal and Greece).

\section{Basic Revenue and Tax Base related Data}

The database contains aggregate nominal data in billions of national currency for the four tax categories and for the respective tax bases on an annual basis. The tax data were taken from the OECD Revenue Statistics database. Sources of tax base data are Ameco and OECD. Annex Table 1 provides an overview of the data, their sources and periods covered.

\section{Asset Price Data}

Real estate prices were provided by the Bank for International Settlements (BIS) and refer to residential property. Stock prices are mainly from BIS and Datastream. All stock indices are broad market indices, not focussed on specific segments. Annex Table 2 provides detailed information about data sources and coverage. 


\section{Regression analysis}

The regressions apply time series analysis on an individual country basis. Tax systems differ across countries so that coefficients and their significance are also likely to differ. Examples for this include differences in the taxation of capital gains (accrued, realised, none), variations in the treatment of mortgage interest deductibility, differences in the importance and dispersion of asset holding and hence wealth effects, etc. Given these significant differences across countries, panel data analysis is less useful.

We apply OLS to test for elasticities of revenue variables to asset price changes. All models are estimated in the first differences of the logarithmic data in order to approximate growth rates. ${ }^{11}$ We take account of potential interaction between tax bases and asset price variables. Multicollinearity, however, turns out not to be a serious concern as correlation coefficients for tax bases and asset price variables are not very high. Other indications of multicollinearity, like equations with a good model fit in combination with poor t-statistics could not be detected either. This result is plausible in the light of the short-run relationship that we examine. ${ }^{12}$.

\section{The Econometric Specifications}

We test two different models. The basic model estimates elasticities of various taxes with respect to their "traditional" base (e.g. compensation of employees), in line with the existing literature analysing budget sensitivities to cyclical fluctuations. This basic model (model 1) has been specified as follows:

(1) $d \ln$ revenue $_{t}=\alpha_{1}+\alpha_{2} * d \ln$ base $_{t, t-1}+e_{t}{ }^{13}$

For the taxes on financial and capital transactions, asset price variables constitute the base and the basic model (1a) looks as follows:

\footnotetext{
${ }^{11}$ This is necessary because of unit roots. We also check for cointegration and estimate an error correction model where needed. We use nominal data in order to avoid problems arising from different deflators. From an econometric point of view this is analogous to using the same deflator for all variables. When assessing the quality of the estimation we apply the following standard tests: Jarque-Bera normality test; Durbin-Watson first-order autocorrelation test; Breusch-Godfrey second-order autocorrelation test; White heteroscedasticity test.

${ }^{12}$ Asset prices and tax bases do not necessarily affect each other very strongly in the short run, whereas they seem to have a stable long-run relationship via output. But this is not subject to our analysis.

${ }^{13}$ In the category direct taxes on companies we use a second lag of the tax base in some cases. This additional lag may be justified as tax legislation can allow significant reperiodization of profits and losses.
} 


$$
d \ln \text { revenue }_{t}=\alpha_{1}+\alpha_{2} * d \ln \text { stockprice }_{t, t-1}+\alpha_{3} * d \ln \text { propertyprice }_{t, t-1}+e_{t}
$$

In the next step the basic model for the estimation of direct and indirect tax effects is augmented by asset price variables to test the hypothesis that these revenue categories are affected by stock and property prices. Moreover, dummy variables are added, as described above. This model (2) is our "best model" and generally takes the following specification ${ }^{14}$ :

$$
\begin{aligned}
& d \ln \text { revenue }_{t}=\alpha_{1}+\alpha_{2} * d \ln \text { base }_{t, t-1}+\alpha_{3} * d \ln \text { propertyprice } \\
& +\alpha_{t, t-1} \\
& +d \ln \text { stockprice }_{t, t-1}+\alpha_{5} * \text { dummy }_{t, t-1}+e_{t}
\end{aligned}
$$

For financial and capital transactions, the basic model is not supplemented by a best model because asset prices already proxy the tax base of the basic model.

\section{4. $\quad$ Results}

\section{A. Qualitative results as to the significance of coefficients}

The estimation results confirm the relevance of our hypotheses for a majority of countries and tax categories. Results are best for transaction and corporate income taxes, followed by indirect and personal income taxes. In about half the countries all four categories are affected by at least one of the asset price variables but all other countries also show at least some impact on revenue from asset price changes. Property prices tend to have a stronger and more significant impact than stock prices on average.

More specifically, Table 1 reports on the qualitative results of estimations across countries, tax categories and assets. A plus indicates a significant coefficient in the respective country and tax category cell. At the bottom of the table, the number of countries for which at least one of the asset price variables proved relevant in explaining the respective revenue is reported. In all countries, asset price changes affect corporate income and capital turnover taxes; in $75 \%$ of them, asset prices affect indirect tax revenue; and in about half the countries personal income tax.

The table also shows that property prices are significantly correlated with indirect and capital transaction taxes in a large number of countries. Real estate-related effects are less significant for direct

\footnotetext{
${ }^{14}$ Model (2) is a standard type of the best model. The exact specification depends on the respective country, the type of tax, the asset price category, and econometric criteria. See table 3 for detailed information.
} 
taxes on corporations and in particular households. Stock prices matter most frequently for corporate income and capital transaction taxes. In 55 of the 67 estimations, at least one of the asset price variables shows a significant effect on revenue.

The last column of Table 1 provides a qualitative indicator of the asset price sensitivity of countries' fiscal variables. It sums the number of tax categories with significant coefficients by country. In about half of the countries, all four revenue categories proved sensitive to property and/or stock price changes, hence an indicator of 4. These include the four Anglo-Saxon countries, Italy, Japan, Norway and Sweden. Denmark, Finland, France, the Netherlands and Spain report three revenue categories with significant coefficients. Switzerland, Belgium, Canada and Germany only report significant effects for two categories (corporate and turnover tax).

\section{B. Quantitative results as to the sign and size of elasticities}

Quantitative results on the effect of asset prices on fiscal variables suggest that such changes are important determinants of revenue. Table 2 reports on these results and provides asset price elasticities according to the asset price augmented regression model (model 2). Elasticities are reported with respect to the periods in which they occur (contemporaneous or lagged; see also Annex Table 3 for more details on the estimations). ${ }^{15}$ For the four tax categories, property prices tend to have larger elasticities than stock price changes. However, given that asset prices are often much more volatile than output with changes of 20 percent or more per annum no rarity and that effects are cumulative over time, even small elasticities can potentially have significant revenue implications. We will return to this question below when we derive asset-price related budget sensitivities.

As regards direct taxes on households, Table 2 finds that a majority of countries report either a significant impact of property or of stock price changes on revenue. The elasticity of revenue to real estate price changes ranges from 0.69 to -0.42 . The comparable figures for stock prices are between 0 and 0.16 . Real estate price increases have an initial negative effect on direct taxes in Australia and the United Kingdom, probably due to rising mortgage interest payments that can be deducted from the income tax burden. In the United Kingdom, the initial negative impact is more than reversed in the following period. In Spain and Sweden, the initial positive effect is subsequently partly reversed. The net (combined 
immediate and lagged) elasticity is always positive except in the case of Australia and ranges up to 0.33 in Italy. ${ }^{16}$ Annex Table 3 shows that the elasticity of the standard tax base (compensation of employees) to revenue generally changes somewhat in the opposite direction of the asset price influence when comparing the basic model (1) with model (2).

As regards direct tax on corporations, all countries report a significant, positive revenue impact of real estate prices, stock prices or both. Elasticities are relatively large for real estate prices (ranging from 0.4 to 1.4 ) and somewhat smaller for stock prices (largely between 0.2 and 0.4 ). The elasticity of the standard tax base (gross operating surplus) to revenue mostly but not always moves closer to one in model 2, compared to model 1 .

As regards indirect taxes via private consumption, a large majority of countries report a significant, positive revenue impact of real estate prices, stock prices or both on private consumption (and thereby indirectly on indirect tax revenue). In four countries, this effect is partly reversed in the following period, as part of the capital gain may be seen as a windfall that leads to a one-off increase in consumption. The net elasticity ranges from 0.03 (Australia) to 0.21 (Denmark) for real estate prices and from 0.02 to 0.04 for stocks. This is consistent with the literature on wealth effects where similar magnitudes for short term stock price-related wealth effects and considerably larger real estate-related effects have been found across countries. ${ }^{17}$ The elasticity of the standard tax base (disposable income) to private consumption declines marginally for most countries when comparing the basic model with the model 2 estimations.

As regards taxes on financial and capital transactions, again all countries report a significant, positive revenue impact of real estate prices, stock prices or both on these taxes. In some cases, this effect is partly reversed in the following period. Elasticities are relatively large for real estate prices (often exceeding 1) and somewhat smaller for stock prices (mostly between 0.2 and 0.5 ).

\section{Improvement in the overall model fit}

The overall model fit improves significantly in most estimations where asset price variables are added and have significant coefficients. Table 3 reports the $\mathrm{R}^{2}$ adjusted for the basic model (1) for all

\footnotetext{
${ }^{15}$ For indirect taxes, Table 2 only reports the elasticity of private consumption to asset prices. However, given that the elasticity of indirect taxes to private consumption is near 1, we prefer to report the unchanged values of the estimations which are consistent with the Annex Table 3 reporting the detailed results.

${ }^{16}$ There are nevertheless some puzzles in these findings, including the relatively high value for Italy and the partial reversal in Spain and Sweden. These are perhaps related to institutional factors in these countries.
} 
countries and for the asset price augmented model (2) for those countries where at least one of the asset price variables has a significant coefficient (except for turnover taxes where there is only one specification). At the bottom of the table, we also report the change in the unweighted average across countries between models (1) and (2), i.e. the average improvement due to adding asset price variables. The greatest improvement in relative and absolute terms is on corporate income tax but the average model fit also improves significantly for the other revenue categories. On top of that F-tests suggest that the 0hypothesis of no significant overall fit can be rejected at the $95 \%$ level in all estimations (except in one case, where it can only be rejected at the $85 \%$ level).

As to direct taxes on households, the goodness of fit on the basis of compensation of employees alone averages 0.5 , ranging from 0.3 to 0.76 . Asset price variables improve this fit in 9 countries by an average of 0.2 , ranging from a marginal increase to an improvement by 0.4.As to direct taxes on corporations, the goodness of fit on the basis of gross operating profits alone averages 0.2 , ranging from near 0 to 0.57 . Asset price variables on average double this value. In all countries, the overall fit improves, ranging from 0.02 to above 0.5. The model fit is highest in Australia, Belgium, France, Japan and the UK. As to indirect taxes via private consumption, the goodness of fit on the basis of disposable income alone is already very high and averages 0.78 . Asset price variables improve this fit by an average of almost 0.1 , with only one country reporting an unchanged model fit (UK) and two countries an improvement of 0.2 or higher. As to taxes on financial and capital transactions, the goodness of fit on the basis of the two types of asset prices variables alone averages near 0.5. Only two countries (Italy and Sweden) report a very low value below 0.25 while Belgium, Finland, Germany and Norway report an R2 adjusted above 0.6.

\section{Asset price-related sensitivities of fiscal variables}

On the basis of the above estimations, we can calculate the sensitivity of revenue and fiscal balances to asset price changes. These sensitivities could be useful both for assessing past biases in fiscal variables and for forecasting fiscal effects of future asset price adjustments. We do so by weighting the

\footnotetext{
${ }^{17}$ Institutional factors (e.g. the holding of real estate and stocks in finds rather than private accounts) may again help explain some peculiarities. However, a more detailed discussion would go beyond the scope of this paper.
} 
estimated elasticities with the revenue share of GDP for each tax category, asset price variable and country. Table 4 reports the results on the basis of 1998 revenue shares in GDP. ${ }^{18}$

For some countries, total sensitivities are relatively modest (0.1-0.2) but for one third they are important (0.3-0.4) and for another third they are very large, reaching or exceeding 0.5 . The latter sensitivity, for example, implies that a 20 percent asset price increase would improve the fiscal balance by 1 percent of GDP, and a reversal of such an increase would have the same adverse effect on a country's fiscal position. While most sensitivities of individual tax categories are relatively small, they add up to significant effects in some countries. Nevertheless, it is difficult to generalise findings, as there are important differences across countries, reflecting also very different tax systems.

Table 4 distinguishes immediate, lagged and combined asset price sensitivities for total revenue and for the four revenue categories. Column 1 reports total sensitivities. These average 0.38 , i.e., a 10 percent increase of both stocks and real estate will raise revenue by $0.38 \%$ of GDP after one period. On average across the 17 countries, most of the effect is immediate. Comparing asset price and output sensitivities of fiscal balances, the effect of the former (looking at a $10 \%$ change) is hence similar on average to the latter (for a $1 \%$ output change). However, differences are enormous and greater than the difference in budget sensitivities across countries. Total elasticities are relatively low between 0 and 0.2 in Australia, Belgium, Canada, France, Germany and Switzerland. Finland, Japan, the Netherlands, Sweden and the US report sensitivities around the average. Denmark, Ireland, Italy, Norway, Spain and the UK show sensitivities of 0.5 or above.

When looking at the sensitivity of fiscal variables to stock versus real estate price changes (acolumns versus b-columns), real estate are clearly more important and explain about two thirds of the overall sensitivity. On average, real estate price changes affect household tax and indirect tax revenue immediately and quite strongly before part of the effect is reversed in the subsequent period in some countries (columns 2a- and 4a). Both real estate and stock prices affect receipts from corporate tax revenue mainly with a lag (columns 3a and 3b).

\footnotetext{
${ }^{18}$ Assume for example, that the estimated elasticity of corporate taxes to real estate price change is 0.5 and the revenue ratio is $4 \%$ of GDP. Assuming linear effects, a 10 percent real estate price increase has a revenue effect of
} 


\section{E. Fiscal balances as affected by the late-1990s property and stock price boom}

The previous findings about the sensitivity of fiscal variables to asset price changes can now be applied to the stock and property price booms in a number of countries in the late 1990s. We looked at 8 countries, including Finland, Ireland, the Netherlands, Norway, Spain, Sweden, the UK and the US to estimate the possible upward bias in fiscal balances due to asset price changes over the 1997-2001 period (assuming implicitly that the former was a year with near "equilibrium" asset prices). In order to be conservative, we only look at real asset price increases (i.e., increases above the CPI) and we apply the sensitivities presented in Table 4 separately for stocks and real estate. Note, however, that we do not know whether 1997 prices were in fact "near equilibrium". Neither do we know whether elasticities can be applied to large asset price changes (although non-linearity tests were not significant). Moreover, another word of caution is warranted as these estimates are based on a 30-year period and may not always reflect the most recent tax regime and/or behaviour of consumers/tax payers.

Table 5 reports the results that suggest a significant upward bias in revenue and fiscal positions in all 8 countries. Real estate prices increased in "real" terms by between 16 and 70 percent over the 1997 to 2001 period and stock prices by -12 to 89 percent. Real estate prices exerted a favourable effect of $0.1 \%$ to $2.5 \%$ of GDP on fiscal balances and stocks between $-0.1 \%$ and $1.5 \%$ of GDP. The total effect is around 1 $1 / 2 \%$ of GDP for most countries and ranges between $0.8 \%$ for the US and $3.0 \%$ for Ireland. Applying our findings symmetrically and not considering the caveats from the previous page, the fiscal balance would also worsen by this magnitude, should "real" asset prices reverse to their 1997 level.

\section{F. Asset price effects on public finances and stabilisation}

Finally, the question arises whether asset price related fiscal effects contribute to economic stabilisation. Asset prices are strongly correlated with output over time. When looking at industrialised country data as used in this study, the correlation between nominal GDP and asset price level indices is largely 0.8 or greater. Nevertheless, the variance of asset price changes is much larger than for output, and the correlation in the rates of changes (short term correlation) is much smaller than in the levels. When looking at long term trend, it also appears that the number of "asset price cycles" seems to be much fewer than the number of business cycles.

$0.2 \%$ of GDP $(10 * 5 \% * 4 \%) .1998$ was chosen as a reference year for revenue shares as the latter were not yet distorted 
If asset prices and the business cycle are correlated, asset price related fiscal effects may to some extent contribute to economic stabilisation, as additional revenue withdraws demand during periods of strong growth and vice versa. Nevertheless, caution is warranted in drawing this conclusion for two reasons. First, some revenue effects are lagged, in particular on corporate tax revenue. Hence, corporate balance sheets and the financial positions of companies, which are probably already suffering from declining profitability at the end of a boom, may be further battered by lagged fiscal obligations from capital gains taxes. Similarly, at the end of a recession rising profitability may coincide with the fiscal effects from writing off earlier capital losses. This may in fact exacerbate the volatility in business behaviour. Assuming a stabilising effect on consumer behaviour, the net effect is unclear.

Another uncertainty is government itself. If for example, additional revenue from asset price increases during an asset price boom coincides with an economic upswing and the government rapidly turns this revenue into higher spending or tax cuts, the stabilising effect may be undone by fiscal loosening. This risk is particularly great if governments are not aware of the transitory nature of such revenue. Deteriorating fiscal balances during an asset price downturn may then induce/require the government to take countervailing restrictive action, compensating any stabilising fiscal effects from the asset price decline.

\section{Conclusion}

We have argued in this paper that fiscal policies and fiscal variables interact with asset prices. As illustrated by a simple accounting framework, the main channel from asset prices to fiscal variables is via direct effects on revenue through capital gains and turnover related taxes, and indirect effects through wealth effects on consumption. Moreover, fiscal effects can rise significantly when the government can be held liable for balance sheet losses incurred during an asset price downturn (e.g. via banking sector support) an issue we did not study further here (but see Eschenbach and Schuknecht, 2002).

An empirical study of the fiscal effects of real estate and house price changes in 17 OECD countries confirms the relevance of such effects. In all countries, corporate income and capital transaction taxes are significantly affected by asset price changes and in a majority of countries this is also true for income taxes on households and indirect taxes. The overall goodness of fit of equations increases

significantly due to asset price related revenue effects from the late 1990s' asset price boom in some countries. 
considerably when asset price variables are added, as compared to the "traditional" literature looking only at fiscal and cyclical variables.

With the findings on the elasticity of fiscal variables to asset price changes it is also possible to calculate revenue and budget sensitivities. We find that in all countries, there is some risk of more variability in fiscal balances due to asset price changes but this risk differs considerably across countries. In $1 / 3$ of the countries, sensitivities are relatively modest whereby a sensitivity of $0.1-0.2$ suggests that a 10 percent increase in house and stock prices yields additional revenue of about $0.1-0.2 \%$ of GDP. In another third, the sensitivity is more important, between 0.3 and 0.4 . In the remaining third of the countries, this sensitivity is 0.5 or higher so that large asset price changes (say, of $20 \%$ ) can have very significant fiscal effects (of 1 percent of GDP or higher). The sensitivity of fiscal variables to house prices explains about $2 / 3$ of the overall sensitivity, although there are considerable differences as to the magnitude and timing across countries. On average the budget sensitivity of a $10 \%$ asset price change is hence quite similar to a $1 \%$ output change.

The findings can be applied to forecasting future fiscal effects of anticipated asset price changes and to analysing recent asset price developments. When applying the estimated elasticities to CPI adjusted real estate and stock price developments between 1997 and 2001 in 8 industrialised countries with significant real estate price increases, we find positive revenue effects of between 0.8 and 3 percent of GDP. This is indicative of an upward bias in fiscal balances which could turn around by a similar magnitude, should asset price reverse. It suggests that a number of countries' fiscal positions are vulnerable to asset price changes and reversals. However, a word of caution is warranted. Equilibrium asset prices are unknown (and any changes hence difficult to predict), elasticities may not be linear for very large asset price changes, and estimates are based on 30 year periods and may not always reflect the most recent tax regime and/or behaviour of consumers/tax payers.

While asset price developments can give rise to significant fiscal effects, the impact on economic stability is not clear. On the one hand, asset prices and growth tend to be correlated (albeit less on a year to year basis) so that the revenue effects may work counter-cyclically. However, revenue effects are often lagged so that a dampening/stimulating effect on demand and corporate financial positions continues well into asset price and (if correlated) conjunctural downturns/upswings. Governments may also countervail the stabilising effect via discretionary tax or expenditure measures. 
As to policy implications, the findings suggest to be cautious when attributing improvements in the fiscal balance beyond normal cyclical effects to structural factors. If asset price related, such factors might prove to be temporary. Moreover, when the additional revenue is treated as permanent by policy makers, it can result in an increase of expenditure commitments or in tax cuts. Fiscal effects from asset price changes are the result of the prevailing fiscal institutions. Governments can assess and if necessary reform its fiscal system in light of its interaction with asset prices. Care should be taken, however, that fiscal reform does not exacerbate the volatility of asset prices and thereby fiscal implications. Finally, governments with fiscal variables sensitive to asset prices and which observe strong asset price increases might consider adjusting their budgetary safety margin to be prepared for the fiscal costs of an eventual downturn. 


\section{Bibliography:}

Bouthevillain, C. Cour-Thimann, P., Van Den Dool, G., Harnandez de Coz, P. Langenus, G., Mohr, M, Momigliano, S. and M. Tujula, (2001) Cyclically Adjusted Budget balances: An Alternative Approach, ECB Working PaperNo. 77.

Buiter, W.II (1989) Principles of Budgetary and Financial Policy, harvester Wheatsheaf, New York.

Caprio, Jr., Gerald, and Klingebiel, Daniela (1996), Bank Insolvencies: Cross-Country Experience, Working Paper 1620, World Bank, Washington.

Case, Karl E., Quigley, John M. and Robert J. Shiller (2001) Comparing Wealth Effects: The Stock Market Versus the Housing Market, NBER Working Paper 8606.

Dai, Qiang,(2000) Ownership Structure, Income Distribution, and Competitive Equilibrium: A theory of Business Cycles, Human Capital and Asset Returns, New York, Stern School of Buisness Mimeo.

Gropp, Reint and Jukka Vesala (2002) Deposit Insurance, Moral Hazard and Market Monitoring, ECB: Mimeo.

Eschenbach, Felix, and Schuknecht, Ludger: (2002), The Fiscal Cost of Financial Instability Revisited, Frankfurt: ECB Mimeo.

European Union, Ameco Database.

Hagemann, P. and Giuseppe Nicoletti (1998) Ageing Populations: Economic Effects and Implications for Public Finance, OECD, Paris.Hemming, R. and M. Petrie (2000) A Framework for Assessing Fiscal Vulnerability, Washington: IMF Working Paper 00/52.

Jonung, Lars and Stymne, Lars, (1997) The Great Regime Shift : Asset Markets and Economic Activity in Sweden, 1985 - 93 , in: Asset Prices and the Real Economy, Capie, Forrest H., pp. 19-55;

Lettau, Martin and Sydney Ludvigson (2001) Understanding Trend and cycle in Asset Values: Bulls, Bears, and the Wealth Effect on Consumption. CEPR DP No. 3104.

Ludwig, Alexander and Torsten Slok (2002) The Impact of Changes in Stock Prices and House Prices on Consumption in OECD Countries, IMF WP 2002/02/01.

McMarrow, Kieran and Werner Roeger (2002) EU Pension Reform - An Overview of the Debate and an Empirical Assessment of the Main Policy Reform Options, DG ECFIN Economic Papers Number 162.

OECD (1998), Revenue Statistics.

Rother, Philipp, Marco Catenaro and Gerhard Schwab (2002) Ageing and Pensions in the Euro Area. Selective Survey and Simulation Results, ECB, Mimeo.

Van Den Noord, P. (2000) The Size and Role of Automatic Fiscal Stabilizers in the 1990s and Beyond, OECD Economics Department Working Papers No. 230. 
Table 1: Qualitative Summary Findings of Asset Price Effects on Different Tax Categories

\begin{tabular}{|c|c|c|c|c|c|c|c|c|c|}
\hline & \multicolumn{2}{|c|}{$\begin{array}{l}\text { direct taxes } \\
\text { on households }\end{array}$} & \multicolumn{2}{|c|}{$\begin{array}{l}\text { direct taxes } \\
\text { on companies }\end{array}$} & \multicolumn{2}{|c|}{ indirect taxes } & \multicolumn{2}{|c|}{$\begin{array}{l}\text { taxes on financial \& } \\
\text { capital transactions }\end{array}$} & \multirow{2}{*}{$\begin{array}{l}\text { number of } \\
\text { significant } \\
\text { tax } \\
\text { categories }\end{array}$} \\
\hline & real estate & stocks & real estate & stocks & real estate & stocks & real estate & stocks & \\
\hline Australia & + & + & + & + & + & 0 & 0 & + & 4 \\
\hline Belgium & 0 & 0 & 0 & + & 0 & 0 & + & + & 2 \\
\hline Canada & 0 & 0 & 0 & + & + & 0 & n.a. & n.a. & 2 \\
\hline Denmark & 0 & 0 & + & 0 & + & 0 & + & + & 3 \\
\hline Finland & 0 & 0 & 0 & + & + & + & + & 0 & 3 \\
\hline France & 0 & 0 & 0 & + & + & 0 & + & + & 3 \\
\hline Germany & 0 & 0 & 0 & + & 0 & 0 & + & 0 & 2 \\
\hline Ireland & 0 & + & 0 & + & + & 0 & + & + & 4 \\
\hline Italy & + & 0 & + & 0 & 0 & + & + & 0 & 4 \\
\hline Japan & 0 & + & + & + & 0 & + & 0 & + & 4 \\
\hline Netherlands & 0 & 0 & 0 & + & + & 0 & + & + & 3 \\
\hline Norway & + & 0 & 0 & + & + & + & + & 0 & 4 \\
\hline Spain & + & 0 & + & + & 0 & 0 & + & 0 & 3 \\
\hline Sweden & + & 0 & 0 & + & + & + & + & 0 & 4 \\
\hline Switzerland & 0 & 0 & + & 0 & 0 & 0 & 0 & + & 2 \\
\hline UK & + & 0 & + & + & + & 0 & + & + & 4 \\
\hline USA & 0 & + & 0 & + & + & + & + & + & 4 \\
\hline Total / averac & & & 17 & & & & & & 3.2 \\
\hline
\end{tabular}


Table 2: Summary of Asset Price Elasticities

\begin{tabular}{|c|c|c|c|c|c|c|c|c|c|}
\hline \multirow{2}{*}{$\begin{array}{l}\text { asset price } \\
\text { category } \\
\text { Australia }\end{array}$} & \multirow{2}{*}{$\frac{\operatorname{lag}}{0}$} & \multicolumn{2}{|c|}{$\begin{array}{l}\text { direct taxes on } \\
\text { households } \\
\text { real estate stocks }\end{array}$} & \multicolumn{2}{|c|}{$\begin{array}{l}\text { direct taxes on } \\
\text { companies } \\
\text { real estate stocks }\end{array}$} & \multicolumn{2}{|c|}{ indirect taxes } & \multicolumn{2}{|c|}{$\begin{array}{l}\text { taxes on financial } \& \\
\text { capital transactions } \\
\text { real estate stocks }\end{array}$} \\
\hline & & - & - & 0.51 & 0.21 & 0.15 & - & - & 0.40 \\
\hline & -1 & -0.42 & 0.09 & - & - & -0.12 & - & - & - \\
\hline & $\Sigma$ & -0.42 & 0.09 & 0.51 & 0.21 & 0.03 & - & - & 0.40 \\
\hline \multirow[t]{3}{*}{ Belgium } & 0 & - & - & - & 0.21 & - & - & 1.19 & 0.44 \\
\hline & -1 & - & - & - & - & - & - & - & - \\
\hline & $\Sigma$ & - & - & - & 0.21 & - & - & 1.19 & 0.44 \\
\hline \multirow[t]{3}{*}{ Canada } & 0 & - & - & - & 0.31 & 0.11 & - & n.a. & n.a. \\
\hline & -1 & - & - & - & - & -0.07 & - & n.a. & n.a. \\
\hline & $\Sigma$ & - & - & - & 0.31 & 0.04 & - & n.a. & n.a. \\
\hline \multirow[t]{3}{*}{ Denmark } & 0 & - & - & - & - & 0.21 & - & 1.06 & - \\
\hline & -1 & - & - & 1.38 & - & - & - & 0.83 & 0.23 \\
\hline & $\Sigma$ & - & - & 1.38 & - & 0.21 & - & 1.89 & 0.23 \\
\hline \multirow[t]{3}{*}{ Finland } & 0 & - & - & - & - & 0.09 & - & 0.70 & - \\
\hline & -1 & - & - & - & 0.30 & - & 0.03 & 0.35 & - \\
\hline & $\Sigma$ & - & - & - & 0.30 & 0.09 & 0.03 & 1.05 & - \\
\hline \multirow[t]{3}{*}{ France } & 0 & - & - & - & - & 0.15 & - & 1.25 & 0.24 \\
\hline & -1 & - & - & - & 0.30 & -0.10 & - & - & - \\
\hline & $\Sigma$ & - & - & - & 0.30 & 0.05 & - & 1.25 & 0.24 \\
\hline \multirow[t]{3}{*}{ Germany } & 0 & - & - & - & 0.24 & - & - & 0.40 & - \\
\hline & -1 & - & - & - & - & - & - & - & - \\
\hline & $\Sigma$ & - & - & - & 0.24 & - & - & 0.40 & - \\
\hline \multirow[t]{3}{*}{ Ireland } & 0 & - & - & - & - & 0.16 & - & 1.40 & 0.23 \\
\hline & -1 & - & 0.10 & - & 0.19 & - & - & - & - \\
\hline & $\Sigma$ & - & 0.10 & - & 0.19 & 0.16 & - & 1.40 & 0.23 \\
\hline \multirow[t]{3}{*}{ Italy } & 0 & 0.33 & - & - & - & - & 0.02 & 0.30 & - \\
\hline & -1 & - & - & 0.46 & - & - & - & - & - \\
\hline & $\Sigma$ & 0.33 & - & 0.46 & - & - & 0.02 & 0.30 & - \\
\hline \multirow[t]{3}{*}{ Japan } & 0 & - & 0.16 & 0.57 & 0.19 & - & 0.02 & - & 0.26 \\
\hline & -1 & - & - & - & - & - & - & - & - \\
\hline & $\Sigma$ & - & 0.16 & 0.57 & 0.19 & - & 0.02 & - & 0.26 \\
\hline Netherlands & 0 & - & - & - & 0.24 & 0.07 & - & 1.11 & 0.27 \\
\hline & -1 & - & - & - & - & - & - & - & - \\
\hline & $\Sigma$ & - & - & - & 0.24 & 0.07 & - & 1.11 & 0.27 \\
\hline Norway & 0 & 0.22 & - & - & - & 0.16 & - & 1.19 & - \\
\hline & -1 & - & - & - & 0.29 & - & 0.04 & - & - \\
\hline & $\Sigma$ & 0.22 & - & - & 0.29 & 0.16 & 0.04 & 1.19 & - \\
\hline Spain & 0 & 0.69 & - & 0.57 & 0.20 & - & - & 0.57 & - \\
\hline & -1 & -0.39 & - & - & - & - & - & - & - \\
\hline & $\Sigma$ & 0.30 & - & 0.57 & 0.20 & - & - & 0.57 & - \\
\hline Sweden & 0 & 0.31 & - & - & 0.44 & 0.26 & 0.03 & 1.95 & - \\
\hline & -1 & -0.24 & 0.00 & - & - & -0.16 & & - & - \\
\hline & $\Sigma$ & 0.07 & 0.00 & - & 0.44 & 0.10 & 0.03 & 1.95 & - \\
\hline Switzerland & 0 & - & - & - & - & - & - & - & 0.46 \\
\hline & -1 & - & - & 0.41 & - & - & - & - & - \\
\hline & $\Sigma$ & - & - & 0.41 & - & - & - & - & 0.46 \\
\hline UK & 0 & -0.16 & - & & - & 0.07 & - & 0.75 & 0.74 \\
\hline & -1 & 0.39 & - & 0.72 & 0.31 & - & - & - & - \\
\hline & $\Sigma$ & 0.23 & - & 0.72 & 0.31 & 0.07 & - & 0.75 & 0.74 \\
\hline USA & 0 & - & - & - & - & 0.16 & 0.02 & 2.45 & 0.46 \\
\hline & -1 & - & 0.16 & - & 0.37 & - & - & - & 0.83 \\
\hline & $\Sigma$ & - & 0.16 & - & 0.37 & 0.16 & 0.02 & 2.45 & 1.29 \\
\hline Average & 0 & 0.08 & 0.01 & 0.10 & 0.12 & 0.09 & 0.01 & 0.84 & 0.22 \\
\hline & -1 & -0.04 & 0.02 & 0.17 & 0.10 & -0.03 & 0.00 & 0.07 & 0.07 \\
\hline & $\Sigma$ & 0.04 & 0.03 & 0.27 & 0.22 & 0.07 & 0.01 & 0.91 & 0.29 \\
\hline Memorandu & ver & elasticiti & s for coun & with sigr & ficant ass & ice effects & only & & \\
\hline & 0 & 0.23 & 0.03 & 0.24 & 0.13 & 0.14 & 0.02 & 1.10 & 0.35 \\
\hline & -1 & -0.11 & 0.06 & 0.42 & 0.13 & -0.04 & 0.01 & 0.09 & 0.11 \\
\hline & $\Sigma$ & 0.12 & 0.09 & 0.66 & 0.26 & 0.10 & 0.03 & 1.19 & 0.46 \\
\hline
\end{tabular}


Table 3: Overall Fit of Estimations (R2 adj.)

1= Model without Asset Prices, 2= Model with Asset Prices 1/

taxes on

financial and

capital

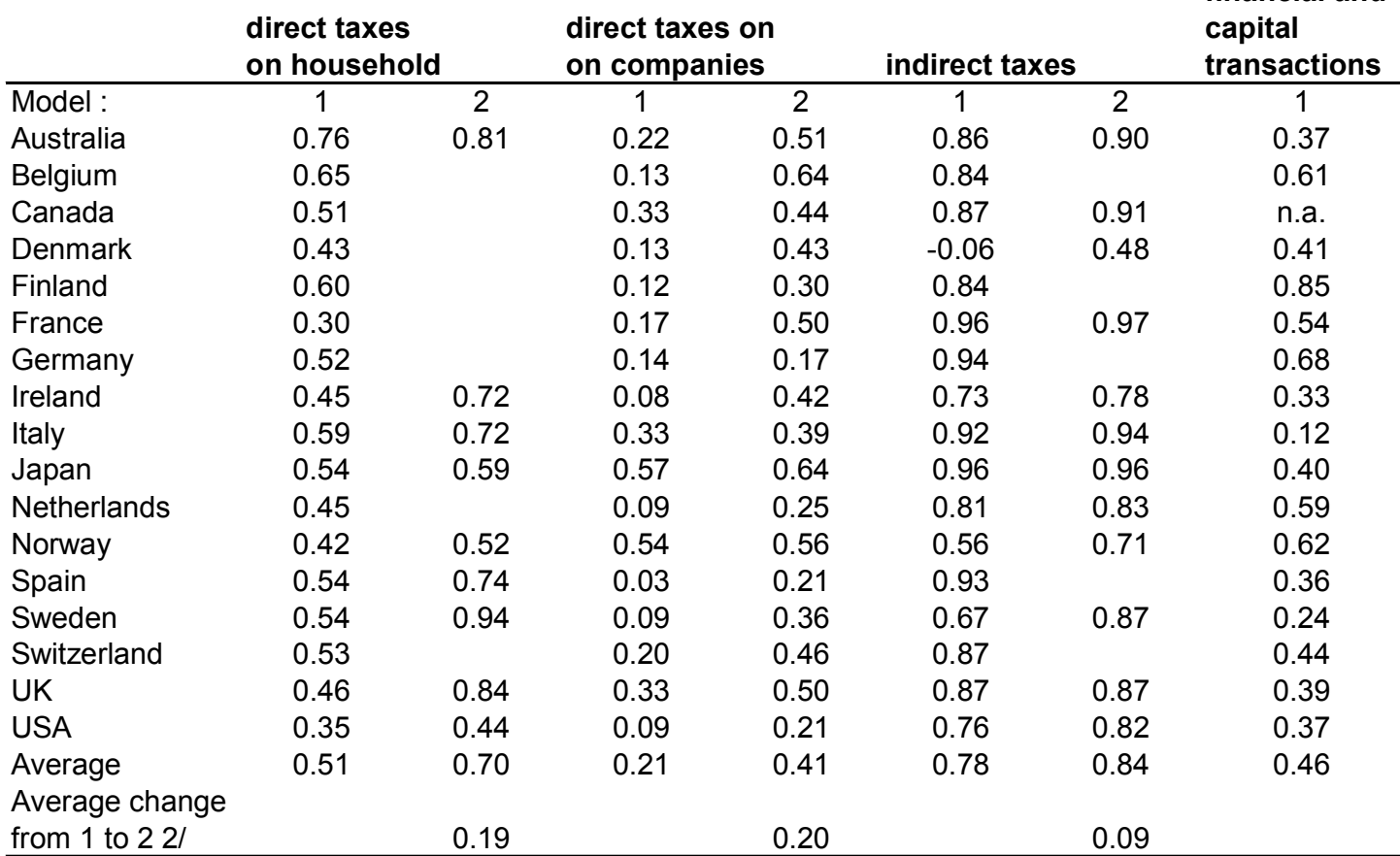

$1 /$ For taxes on financial and capital transactions, in model 1 asset prices proxy tax bases

$2 /$ Change in average from 1 to 2 only refers to countries with significant asset price effects 
Table 4: Asset Price Related Budget Sensitivities

Increase/Decrease in Revenue, Given a 10\% Asset Price Increase, in \% of GDP

\begin{tabular}{|c|c|c|c|}
\hline $\begin{array}{l}\text { direct taxes } \\
\text { on households }\end{array}$ & $\begin{array}{l}\text { direct taxes on } \\
\text { companies }\end{array}$ & indirect taxes & $\begin{array}{l}\text { taxes on financial } \\
\text { and capital } \\
\text { transactions }\end{array}$ \\
\hline
\end{tabular}

lag 1/ Total (1) real estate stocks real estate stocks real estate stocks real estate stocks

\begin{tabular}{|c|c|c|c|c|c|c|c|c|c|c|}
\hline & & & (2a) & $(2 b)$ & (3a) & $(3 b)$ & $(4 a)$ & $(4 b)$ & (5a) & (5b) \\
\hline \multirow[t]{3}{*}{ Australia } & 0 & 0.5 & & & 0.23 & 0.09 & 0.11 & & & 0.06 \\
\hline & -1 & -0.5 & -0.56 & 0.12 & & & -0.09 & & & \\
\hline & $\Sigma$ & 0.0 & -0.56 & 0.12 & 0.23 & 0.09 & 0.02 & & & 0.06 \\
\hline \multirow[t]{3}{*}{ Belgium } & 0 & 0.2 & & & & & & & 0.12 & 0.04 \\
\hline & -1 & 0.0 & & & & & & & & \\
\hline & $\sum$ & 0.2 & & & & & & & 0.12 & 0.04 \\
\hline \multirow[t]{3}{*}{ Canada } & 0 & 0.2 & & & & 0.12 & 0.10 & & & \\
\hline & -1 & -0.1 & & & & & -0.07 & & & \\
\hline & $\Sigma$ & 0.2 & & & & 0.12 & 0.04 & & & \\
\hline \multirow[t]{3}{*}{ Denmark } & 0 & 0.4 & & & & & 0.35 & & 0.07 & \\
\hline & -1 & 0.4 & & & 0.39 & & & & 0.05 & 0.01 \\
\hline & $\Sigma$ & 0.9 & & & 0.39 & & & & 0.11 & 0.01 \\
\hline \multirow[t]{3}{*}{ Finland } & 0 & 0.2 & & & & & 0.13 & & 0.03 & \\
\hline & -1 & 0.2 & & & & 0.12 & & 0.04 & 0.01 & \\
\hline & $\sum$ & 0.3 & & & & 0.12 & 0.13 & 0.04 & 0.04 & \\
\hline \multirow[t]{3}{*}{ France } & 0 & 0.3 & & & & & 0.18 & & 0.06 & 0.01 \\
\hline & -1 & 0.0 & & & & 0.08 & -0.12 & & & \\
\hline & $\Sigma$ & 0.2 & & & & 0.08 & 0.06 & & 0.06 & 0.01 \\
\hline \multirow[t]{3}{*}{ Germany } & 0 & 0.1 & & & & 0.04 & & & 0.01 & \\
\hline & -1 & 0.0 & & & & & & & & \\
\hline & $\Sigma$ & 0.1 & & & & 0.04 & & & 0.01 & \\
\hline \multirow[t]{3}{*}{ Ireland } & 0 & 0.3 & & & & & 0.20 & & 0.11 & 0.02 \\
\hline & -1 & 0.2 & & 0.10 & & 0.06 & & & & \\
\hline & $\sum$ & 0.5 & & 0.10 & & 0.06 & 0.20 & & 0.11 & 0.02 \\
\hline \multirow[t]{3}{*}{ Italy } & 0 & 0.4 & 0.35 & & & & & 0.02 & 0.03 & \\
\hline & -1 & 0.1 & & & 0.14 & & & & & \\
\hline & $\Sigma$ & 0.5 & 0.35 & & 0.14 & & & 0.02 & 0.03 & \\
\hline \multirow[t]{3}{*}{ Japan } & 0 & 0.4 & & 0.08 & 0.22 & 0.07 & & 0.01 & & 0.01 \\
\hline & -1 & 0.0 & & & & & & & & \\
\hline & $\Sigma$ & 0.4 & & 0.08 & 0.22 & 0.07 & & 0.01 & & 0.01 \\
\hline \multirow[t]{3}{*}{ Netherlands } & 0 & 0.3 & & & & 0.10 & 0.08 & & 0.08 & 0.02 \\
\hline & -1 & 0.0 & & & & & & & & \\
\hline & $\Sigma$ & 0.3 & & & & 0.10 & 0.08 & & 0.08 & 0.02 \\
\hline \multirow[t]{3}{*}{ Norway } & 0 & 0.5 & 0.26 & & & & 0.26 & & 0.02 & \\
\hline & -1 & 0.2 & & & & 0.12 & & 0.06 & & \\
\hline & $\Sigma$ & 0.7 & 0.26 & & & 0.12 & 0.26 & 0.06 & 0.02 & \\
\hline \multirow[t]{3}{*}{ Spain } & 0 & 0.7 & 0.49 & & 0.14 & 0.05 & & & 0.05 & \\
\hline & -1 & -0.3 & -0.28 & & & & & & & \\
\hline & $\Sigma$ & 0.5 & 0.21 & & 0.14 & 0.05 & & & 0.05 & \\
\hline \multirow[t]{3}{*}{ Sweden } & 0 & 1.1 & 0.56 & & & 0.13 & 0.29 & 0.03 & 0.04 & \\
\hline & -1 & -0.6 & -0.44 & & & & -0.18 & & & \\
\hline & $\Sigma$ & 0.4 & 0.13 & & & 0.13 & 0.11 & 0.03 & 0.04 & \\
\hline Switzerland & 0 & 0.0 & & & & & & & & 0.05 \\
\hline & -1 & 0.1 & & & 0.09 & & & & & \\
\hline & $\Sigma$ & 0.1 & & & 0.09 & & & & & 0.05 \\
\hline UK & 0 & 0.0 & -0.16 & & & & 0.08 & & 0.04 & 0.04 \\
\hline & -1 & 0.8 & 0.39 & & 0.30 & 0.13 & & & & \\
\hline & $\Sigma$ & 0.8 & 0.23 & & 0.30 & 0.13 & 0.08 & & 0.04 & 0.04 \\
\hline USA & 0 & 0.1 & & & & & 0.07 & 0.01 & 0.01 & 0.00 \\
\hline & -1 & 0.3 & & 0.18 & & 0.10 & & & & 0.00 \\
\hline & $\Sigma$ & 0.4 & & 0.18 & & 0.10 & 0.07 & 0.01 & 0.01 & 0.01 \\
\hline Average total & 0 & 0.33 & 0.09 & 0.00 & 0.03 & 0.04 & 0.11 & 0.00 & 0.04 & 0.02 \\
\hline & -1 & 0.05 & -0.05 & 0.02 & 0.05 & 0.04 & -0.03 & 0.01 & 0.00 & 0.00 \\
\hline & $\Sigma$ & 0.38 & 0.04 & 0.03 & 0.09 & 0.07 & 0.08 & 0.01 & 0.05 & 0.02 \\
\hline Memorandum: & vera & ssitivities & untries & h signi & nt asse & rice eff & s only & & & \\
\hline & 0 & & 0.25 & 0.01 & 0.08 & 0.04 & 0.17 & 0.01 & 0.05 & 0.02 \\
\hline & -1 & & -0.15 & 0.07 & 0.13 & 0.04 & -0.04 & 0.02 & 0.00 & 0.00 \\
\hline & $\Sigma$ & & 0.10 & 0.08 & 0.21 & 0.09 & 0.13 & 0.03 & 0.06 & 0.03 \\
\hline
\end{tabular}

$1 / 0=$ current, $-1=$ first lag

Source: OECD revenue statistics and own calculations 
Table 5: Excess Revenue in 2001 , Compared to 1997, Estimation Based

\begin{tabular}{lccccc} 
& $\begin{array}{l}\text { \% change } \\
\text { real estate } \\
\text { price index 1/ }\end{array}$ & $\begin{array}{l}\text { Real estate rel. } \\
\text { budget effect } \\
\text { \% of GDP }\end{array}$ & $\begin{array}{l}\text { \% change } \\
\text { stock price } \\
\text { index } 1 /\end{array}$ & $\begin{array}{l}\text { Stock price rel. } \\
\text { budget effect } \\
\text { \% of GDP }\end{array}$ & $\begin{array}{l}\text { Total asset } \\
\text { price related } \\
\text { budget effects } \\
\text { \% of GDP }\end{array}$ \\
\hline Finland & 19.7 & 0.3 & 89.2 & 1.5 & 1.8 \\
Ireland & 70.4 & 2.2 & 46.1 & 0.8 & 3.0 \\
Netherlands & 53.8 & 1.4 & 8.4 & 0.0 & 1.4 \\
Norway & 33.6 & 1.4 & -11.6 & -0.1 & 1.3 \\
Spain & 27.8 & 1.1 & 16.8 & 0.1 & 1.2 \\
Sweden & 38.9 & 1.1 & 19.2 & 0.3 & 1.4 \\
UK & 39.0 & 2.5 & -1.9 & 0.0 & 2.5 \\
USA & 16.2 & 0.1 & 24.3 & 0.7 & 0.8 \\
\hline
\end{tabular}

Source: BIS, Datastream, and own calculations base on Table 4.

1/ CPI adjusted 
Annex Table 1: Revenue and tax base catogories, data sources, and time coverage

\begin{tabular}{|l|l|l|}
\hline Data category & Source & Period covered \\
\hline Direct taxes on households & OECD & $1965-2000$ \\
\hline $\begin{array}{l}\text { Direct taxes on companies } \\
\text { Indirect taxes }\end{array}$ & OECD & $1965-2000$ \\
\hline Taxes on financial and capital transactions & OECD & $1965-2000$ \\
\hline Compensation of employees & Ameco & $1965-1998$, missing: Canada \\
\hline Gross operating surplus & Ameco & $1960-2000$ \\
\hline Private consumption & Ameco & $1960-2000$ \\
\hline Disposable income & OECD & $\begin{array}{l}1960-2000, \text { except country series starting later: } \\
\text { Belgium (1970), Canada (1961), Denmark }\end{array}$ \\
& & $\begin{array}{l}(1981), \text { Spain (1964), Finland (1970), Ireland } \\
(1977), \text { Italy (1961), Netherlands (1970), }\end{array}$ \\
\hline Gross domestic product & & Norway (1975), all ending in 2000 \\
\hline
\end{tabular}

Annex Table 2: Asset price indices, data sources and time coverage

\begin{tabular}{|c|c|c|}
\hline Asset price index & Source & Period covered \\
\hline Stock price index & BIS & $\begin{array}{l}\text { Canada, Finland, Germany, Japan, Norway, } \\
\text { USA (1960-2000), Switzerland (1960-1997), } \\
\text { UK (1963-2000) }\end{array}$ \\
\hline Stock price index & Datastream & $\begin{array}{l}\text { Australia, Belgium, Denmark, France, Ireland, Italy, Netherlands } \\
(1973-2000)\end{array}$ \\
\hline Stock price index & $\begin{array}{l}\text { Bank of Spain } \\
\text { AFV Affaers- } \\
\text { Vaerlden }\end{array}$ & $\begin{array}{l}\text { Spain }(1961-2000) \\
\text { Sweden }(1960-2000)\end{array}$ \\
\hline $\begin{array}{l}\text { Real estate price } \\
\text { index } \\
\text { (residential) }\end{array}$ & BIS & $\begin{array}{l}\text { 1960-2000, except country series starting later: } \\
\text { Netherlands (1965), USA (1968), UK (1969), Canada, Denmark, } \\
\text { Norway, Finland, Ireland, Switzerland, Sweden (1970), Germany } \\
\text { (1971), Italy (1972), Spain (1975) }\end{array}$ \\
\hline
\end{tabular}




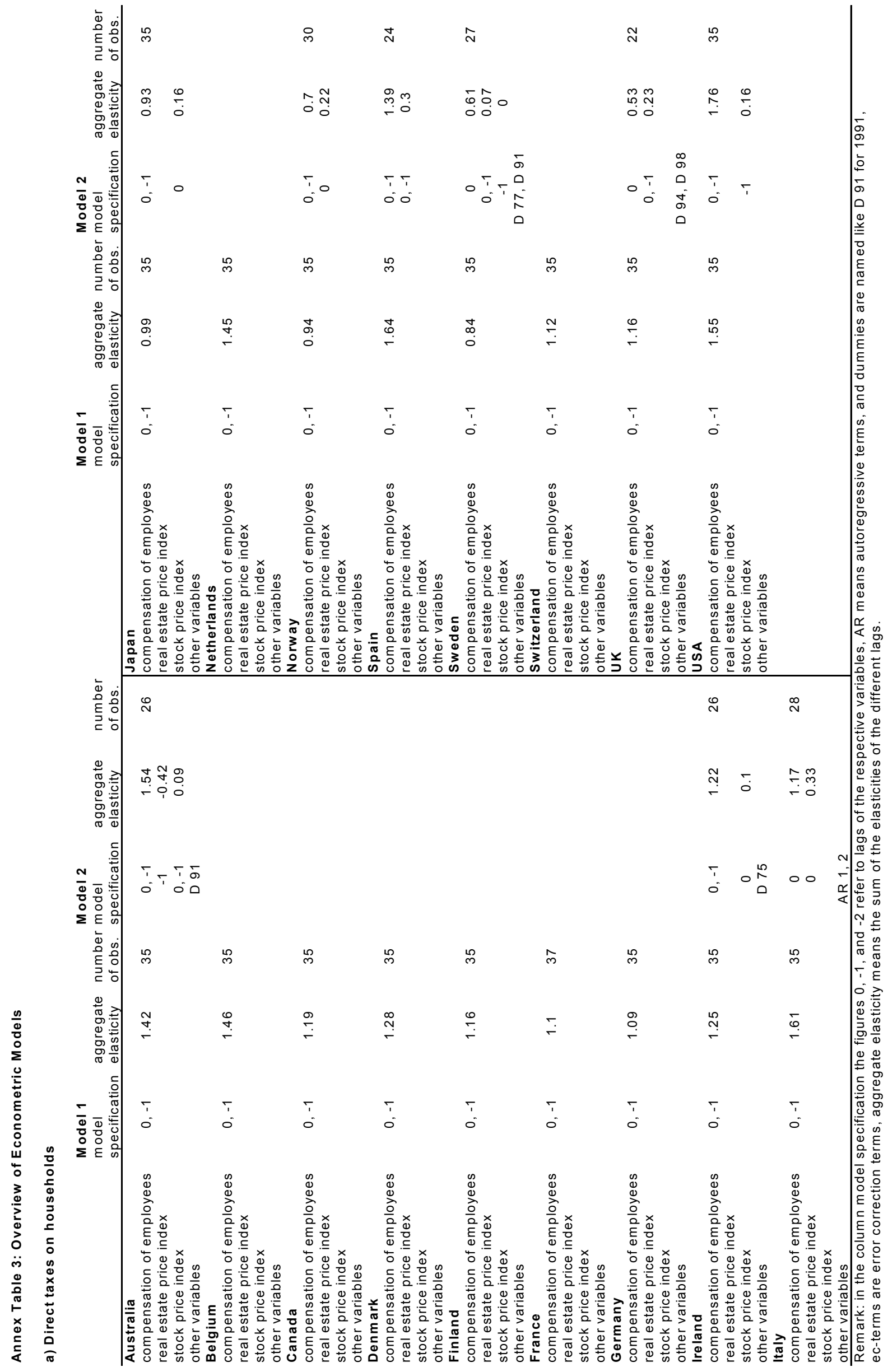




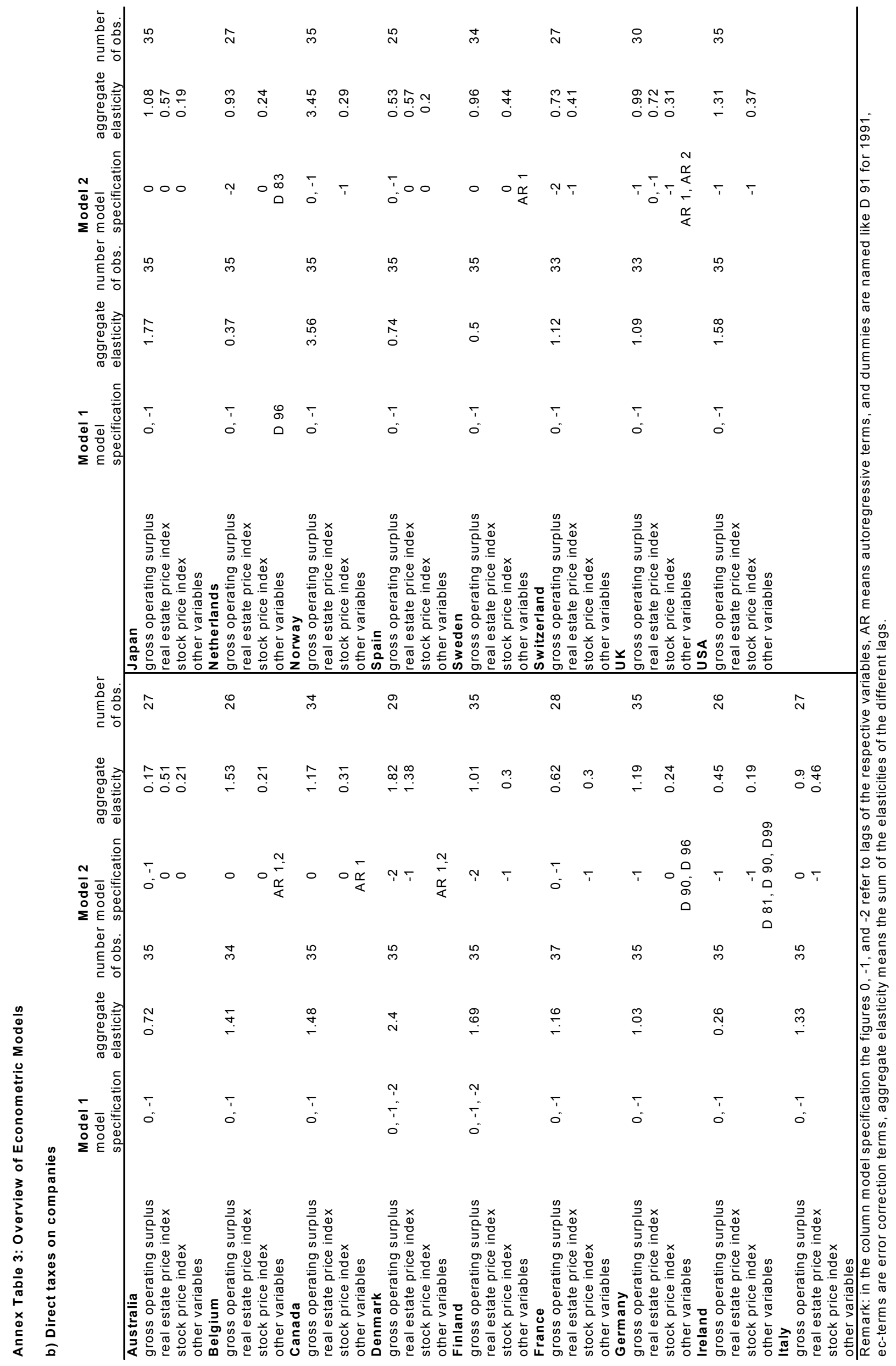




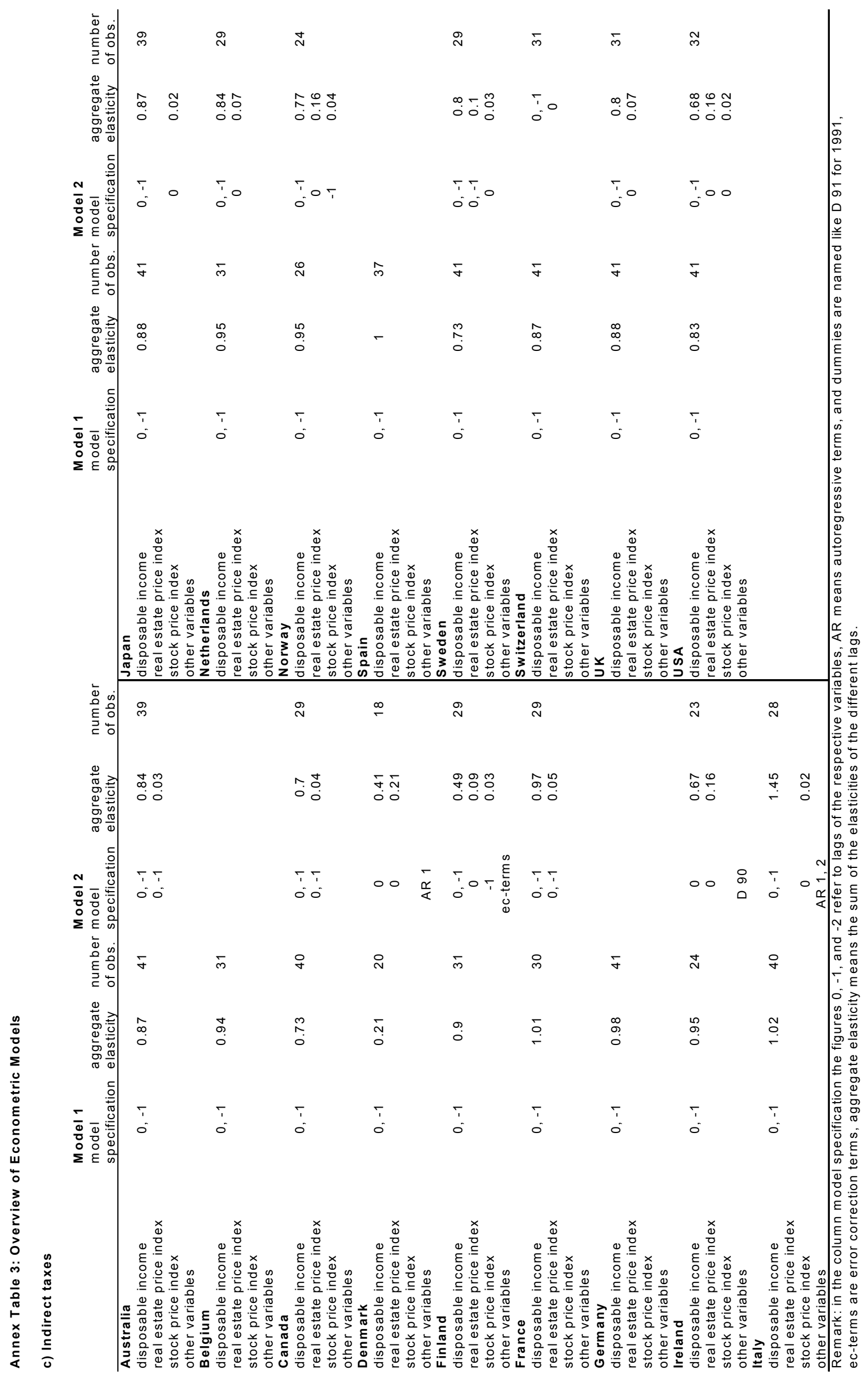




\begin{tabular}{|c|c|c|c|c|c|c|c|}
\hline & $\begin{array}{l}\text { Model } 1 \\
\text { model } \\
\text { specification }\end{array}$ & $\begin{array}{l}\text { aggregate } \\
\text { elasticity }\end{array}$ & $\begin{array}{l}\text { number } \\
\text { of obs. }\end{array}$ & & $\begin{array}{l}\text { Model } 1 \\
\text { model } \\
\text { specification }\end{array}$ & $\begin{array}{l}\text { aggregate } \\
\text { elasticity }\end{array}$ & $\begin{array}{l}\text { number } \\
\text { of obs. }\end{array}$ \\
\hline Australia & & & & Japan & & & \\
\hline real estate price index & & & 25 & real estate price index & & & 31 \\
\hline stock price index & 0 & 0.4 & & stock price index & 0 & 0.26 & \\
\hline other variables & & & & other variables & AR 1, 2 & & \\
\hline Belgium & & & & Netherlands & & & \\
\hline real estate price index & 0 & 1.19 & 25 & real estate price index & 0 & 1.11 & 25 \\
\hline stock price index & 0 & 0.44 & & stock price index & 0 & 0.27 & \\
\hline other variables & AR 1, 2 & & & other variables & AR 1, 2 & & \\
\hline Canada & & & & Norway & & & \\
\hline real estate price index & n.a. & n.a. & & real estate price index & $0,-1,-2$ & 1.19 & 26 \\
\hline $\begin{array}{l}\text { stock price index } \\
\text { other variables }\end{array}$ & n.a. & n.a. & & $\begin{array}{l}\text { stock price index } \\
\text { other variables }\end{array}$ & & & \\
\hline Denmark & & & & Spain & & & \\
\hline real estate price index & $0,-1$ & 1.89 & 24 & real estate price index & 0 & 0.57 & 23 \\
\hline stock price index & -1 & 0.23 & & stock price index & & & \\
\hline other variables & & & & other variables & AR 1 & & \\
\hline Finland & & & & Sweden & & & \\
\hline $\begin{array}{l}\text { real estate price index } \\
\text { stock price index }\end{array}$ & $\begin{array}{c}0,-1 \\
\text { D } 90, \text { D } 94\end{array}$ & 1.05 & 27 & $\begin{array}{l}\text { real estate price index } \\
\text { stock price index }\end{array}$ & 0 & 1.95 & 28 \\
\hline other variables & & & & other variables & AR 1 & & \\
\hline France & & & & Switzerland & & & \\
\hline real estate price index & 0 & 1.25 & 24 & real estate price index & & & 31 \\
\hline stock price index & 0 & 0.24 & & stock price index & 0 & 0.46 & \\
\hline other variables & AR 1 & & & other variables & AR 1 & & \\
\hline Germany & & & & UK & & & \\
\hline real estate price index & $0,-1$ & 0.4 & 26 & real estate price index & 0 & 0.75 & 29 \\
\hline stock price index & $0,-1$ & & & stock price index & 0 & 0.74 & \\
\hline other variables & AR 1, 2 & & & other variables & AR 1 & & \\
\hline Ireland & & & & USA & & & \\
\hline real estate price index & 0 & 1.4 & 25 & real estate price index & 0 & 2.45 & 30 \\
\hline stock price index & 0 & 0.23 & & stock price index & $0,-1$ & 1.29 & \\
\hline other variables & AR 1, 2 & & & other variables & AR 1 & & \\
\hline Italy & & & & & & & \\
\hline $\begin{array}{l}\text { real estate price index } \\
\text { stock price index }\end{array}$ & 0 & 0.3 & 26 & & & & \\
\hline other variables & AR 1,2 & & & & & & \\
\hline
\end{tabular}

Remark: in the column model specification the figures $0,-1$, and -2 refer to lags of the respective variables,

AR means autoregressive terms, and dummies are named like D 91 for 1991, ec-terms are error correction terms, aggregate elasticity means the sum of the elasticities of the different lags. 


\section{European Central Bank Working Paper Series}

I "A global hazard index for the world foreign exchange markets" by V. Brousseau and $F$. Scacciavillani, May 1999.

2 "What does the single monetary policy do? A SVAR benchmark for the European Central Bank" by C. Monticelli and O. Tristani, May 1999.

3 "Fiscal policy effectiveness and neutrality results in a non-Ricardian world" by C. Detken, May 1999.

4 "From the ERM to the euro: new evidence on economic and policy convergence among EU countries” by I. Angeloni and L. Dedola, May 1999.

5 “Core inflation: a review of some conceptual issues" by M. Wynne, May 1999.

6 "The demand for M3 in the euro area" by G. Coenen and J.-L. Vega, September 1999.

7 "A cross-country comparison of market structures in European banking" by O. de Bandt and E. P. Davis, September 1999.

8 “Inflation zone targeting" by A. Orphanides and V. Wieland, October 1999.

9 "Asymptotic confidence bands for the estimated autocovariance and autocorrelation functions of vector autoregressive models" by G. Coenen, January 2000.

10 "On the effectiveness of sterilized foreign exchange intervention" by R. Fatum, February 2000.

II "Is the yield curve a useful information variable for the Eurosystem?" by J. M. Berk and P. van Bergeijk, February 2000.

12 “Indicator variables for optimal policy" by L. E. O. Svensson and M. Woodford, February 2000.

13 “Monetary policy with uncertain parameters” by U. Söderström, February 2000.

14 "Assessing nominal income rules for monetary policy with model and data uncertainty" by G. D. Rudebusch, February 2000.

15 "The quest for prosperity without inflation" by A. Orphanides, March 2000.

16 "Estimating the implied distribution of the future short term interest rate using the Longstaff-Schwartz model” by P. Hördahl, March 2000.

17 "Alternative measures of the NAIRU in the euro area: estimates and assessment" by S. Fabiani and R. Mestre, March 2000.

18 "House prices and the macroeconomy in Europe: Results from a structural VAR analysis" by M. lacoviello, April 2000. 
19 "The euro and international capital markets" by C. Detken and P. Hartmann, April 2000.

20 "Convergence of fiscal policies in the euro area" by O. De Bandt and F. P. Mongelli, May 2000.

2I "Firm size and monetary policy transmission: evidence from German business survey data" by M. Ehrmann, May 2000 .

22 "Regulating access to international large value payment systems" by C. Holthausen and T. Rønde, June 2000.

23 “Escaping Nash inflation” by In-Koo Cho and T. J. Sargent, June 2000.

24 "What horizon for price stability” by F. Smets, July 2000.

25 "Caution and conservatism in the making of monetary policy" by P. Schellekens, July 2000.

26 "Which kind of transparency? On the need for clarity in monetary policy-making" by B. Winkler, August 2000.

27 "This is what the US leading indicators lead" by M. Camacho and G. Perez-Quiros, August 2000.

28 "Learning, uncertainty and central bank activism in an economy with strategic interactions" by M. Ellison and N. Valla, August 2000.

29 "The sources of unemployment fluctuations: an empirical application to the Italian case" by S. Fabiani, A. Locarno, G. Oneto and P. Sestito, September 2000.

30 "A small estimated euro area model with rational expectations and nominal rigidities" by G. Coenen and V. Wieland, September 2000.

3I “The disappearing tax base: Is foreign direct investment eroding corporate income taxes?" by R. Gropp and K. Kostial, September 2000.

32 "Can indeterminacy explain the short-run non-neutrality of money?" by F. De Fiore, September 2000.

33 "The information content of M3 for future inflation" by C. Trecroci and J. L. Vega, October 2000.

34 "Capital market development, corporate governance and the credibility of exchange rate pegs” by O. Castrén and T. Takalo, October 2000.

35 “Systemic risk: A survey" by O. De Bandt and P. Hartmann, November 2000.

36 "Measuring core inflation in the euro area" by C. Morana, November 2000.

37 "Business fixed investment: Evidence of a financial accelerator in Europe" by P. Vermeulen, November 2000. 
38 "The optimal inflation tax when taxes are costly to collect" by F. De Fiore, November 2000.

39 "A money demand system for euro area M3" by C. Brand and N. Cassola, November 2000.

40 "Financial structure and the interest rate channel of ECB monetary policy" by B. Mojon, November 2000.

41 "Why adopt transparency? The publication of central bank forecasts" by P. M. Geraats, January 2001 .

42 "An area-wide model (AWM) for the euro area" by G. Fagan, J. Henry and R. Mestre, January 2001 .

43 "Sources of economic renewal: from the traditional firm to the knowledge firm" by D. R. Palenzuela, February 2001.

44 "The supply and demand for eurosystem deposits - The first 18 months" by U. Bindseil and F. Seitz, February 2001.

45 "Testing the Rank of the Hankel matrix: a statistical approach" by G. Camba-Mendez and G. Kapetanios, February $200 \mathrm{I}$.

46 "A two-factor model of the German term structure of interest rates" by N. Cassola and J. B. Luís, February 2001.

47 "Deposit insurance and moral hazard: does the counterfactual matter?" by R. Gropp and J. Vesala, February 200I.

48 "Financial market integration in Europe: on the effects of EMU on stock markets" by M. Fratzscher, March 200I.

49 "Business cycle and monetary policy analysis in a structural sticky-price model of the euro area” by M. Casares, March $200 \mathrm{I}$.

50 "Employment and productivity growth in service and manufacturing sectors in France, Germany and the US" by T. von Wachter, March 2001.

$5 I$ "The functional form of the demand for euro area MI" by L. Stracca, March 200 I.

52 "Are the effects of monetary policy in the euro area greater in recessions than in booms?" by G. Peersman and F. Smets, March 2001 .

53 "An evaluation of some measures of core inflation for the euro area" by J.-L. Vega and M. A. Wynne, April 200I.

54 “Assessment criteria for output gap estimates” by G. Camba-Méndez and D. R. Palenzuela, April 2001. 
55 "Modelling the demand for loans to the private sector in the euro area" by A. Calza, G. Gartner and J. Sousa, April 200 I.

56 "Stabilization policy in a two country model and the role of financial frictions" by E. Faia, April 200I.

57 “Model-based indicators of labour market rigidity" by S. Fabiani and D. RodriguezPalenzuela, April 200I.

58 "Business cycle asymmetries in stock returns: evidence from higher order moments and conditional densities” by G. Perez-Quiros and A. Timmermann, April 200 I.

59 "Uncertain potential output: implications for monetary policy" by M. Ehrmann and F. Smets, April 2001.

60 "A multi-country trend indicator for euro area inflation: computation and properties" by E. Angelini, J. Henry and R. Mestre, April 2001.

6I "Diffusion index-based inflation forecasts for the euro area" by E. Angelini, J. Henry and R. Mestre, April 2001.

62 "Spectral based methods to identify common trends and common cycles" by G. C. Mendez and G. Kapetanios, April 200 I.

63 "Does money lead inflation in the euro area?" by S. N. Altimari, May 200I.

64 "Exchange rate volatility and euro area imports" by R. Anderton and F. Skudelny, May 200I.

65 "A system approach for measuring the euro area NAIRU” by S. Fabiani and R. Mestre, May 200I.

66 "Can short-term foreign exchange volatility be predicted by the Global Hazard Index?" by V. Brousseau and F. Scacciavillani, June 2001 .

67 "The daily market for funds in Europe: Has something changed with the EMU?" by G. P. Quiros and H. R. Mendizabal, June 200I.

68 "The performance of forecast-based monetary policy rules under model uncertainty" by A. Levin, V. Wieland and J. C.Williams, July $200 \mathrm{I}$.

69 "The ECB monetary policy strategy and the money market" by V. Gaspar, G. Perez-Quiros and J. Sicilia, July $200 \mathrm{I}$.

70 "Central Bank forecasts of liquidity factors: Quality, publication and the control of the overnight rate” by U. Bindseil, July 2001.

7I “Asset market linkages in crisis periods” by P. Hartmann, S. Straetmans and C. G. de Vries, July 200I.

72 "Bank concentration and retail interest rates" by S. Corvoisier and R. Gropp, July 200 I. 
73 "Interbank lending and monetary policy transmission - evidence for Germany" by M. Ehrmann and A. Worms, July 2001.

74 "Interbank market integration under asymmetric information" by $\mathrm{X}$. Freixas and C. Holthausen, August $200 \mathrm{I}$.

75 "Value at risk models in finance" by S. Manganelli and R. F. Engle, August 200I.

76 "Rating agency actions and the pricing of debt and equity of European banks: What can we infer about private sector monitoring of bank soundness?" by R. Gropp and A. J. Richards, August 200I.

77 "Cyclically adjusted budget balances: An alternative approach" by C. Bouthevillain, P. CourThimann, G. van den Dool, P. Hernández de Cos, G. Langenus, M. Mohr, S. Momigliano and M. Tujula, September 200I.

78 "Investment and monetary policy in the euro area" by B. Mojon, F. Smets and P. Vermeulen, September 200I.

79 "Does liquidity matter? Properties of a synthetic divisia monetary aggregate in the euro area" by L. Stracca, October 200 I.

80 "The microstructure of the euro money market" by P. Hartmann, M. Manna and A. Manzanares, October 2001.

8I "What can changes in structural factors tell us about unemployment in Europe?" by J. Morgan and A. Mourougane, October 200I.

82 "Economic forecasting: some lessons from recent research" by D. Hendry and M. Clements, October 200I.

83 "Chi-squared tests of interval and density forecasts, and the Bank of England's fan charts" by K. F. Wallis, November 2001.

84 "Data uncertainty and the role of money as an information variable for monetary policy" by G. Coenen, A. Levin and V. Wieland, November 200I.

85 "Determinants of the euro real effective exchange rate: a BEER/PEER approach" by F. Maeso-Fernandez, C. Osbat and B. Schnatz, November 2001.

86 "Rational expectations and near rational alternatives: how best to form expecations" by M. Beeby, S. G. Hall and S. B. Henry, November 200I.

87 “Credit rationing, output gap and business cycles" by F. Boissay, November $200 \mathrm{I}$.

88 "Why is it so difficult to beat the random walk forecast of exchange rates?" by L. Kilian and M. P. Taylor, November 2001. 
89 "Monetary policy and fears of financial instability" by V. Brousseau and C. Detken, November 200I.

90 “Public pensions and growth" by S. Lambrecht, P. Michel and J.-P. Vidal, November 200 I.

91 "The monetary transmission mechanism in the euro area: more evidence from VAR analysis" by G. Peersman and F. Smets, December 2001.

92 "A VAR description of the effects of monetary policy in the individual countries of the euro area” by B. Mojon and G. Peersman, December $200 \mathrm{I}$.

93 "The monetary transmission mechanism at the euro-area level: issues and results using structural macroeconomic models" by P. McAdam and J. Morgan, December $200 \mathrm{I}$.

94 "Monetary policy transmission in the euro area: what do aggregate and national structural models tell us?" by P. van Els, A. Locarno, J. Morgan and J.-P. Villetelle, December 200 I.

95 "Some stylised facts on the euro area business cycle" by A.-M. Agresti and B. Mojon, December 2001.

96 "The reaction of bank lending to monetary policy measures in Germany" by A. Worms, December 200 I.

97 "Asymmetries in bank lending behaviour. Austria during the 1990s" by S. Kaufmann, December $200 \mathrm{I}$.

98 "The credit channel in the Netherlands: evidence from bank balance sheets" by L. De Haan, December 200I.

99 "Is there a bank lending channel of monetary policy in Spain?" by I. Hernando and J. Martínez-Pagés, December 2001.

100 "Transmission of monetary policy shocks in Finland: evidence from bank level data on loans" by J. Topi and J. Vilmunen, December $200 \mathrm{I}$.

I0I "Monetary policy and bank lending in France: are there asymmetries?" by C. Loupias, F. Savignac and P. Sevestre, December 200I.

102 "The bank lending channel of monetary policy: identification and estimation using Portuguese micro bank data” by L. Farinha and C. Robalo Marques, December $200 \mathrm{I}$.

103 "Bank-specific characteristics and monetary policy transmission: the case of Italy" by L. Gambacorta, December 200I.

104 "Is there a bank lending channel of monetary policy in Greece? Evidence from bank level data” by S. N. Brissimis, N. C. Kamberoglou and G. T. Simigiannis, December 200 I.

105 "Financial systems and the role of banks in monetary policy transmission in the euro area" by M. Ehrmann, L. Gambacorta, J. Martínez-Pagés, P. Sevestre and A. Worms, December 200I. 
106 "Investment, the cost of capital, and monetary policy in the nineties in France: a panel data investigation" by J.-B. Chatelain and A. Tiomo, December 2001.

107 "The interest rate and credit channel in Belgium: an investigation with micro-level firm data" by P. Butzen, C. Fuss and P. Vermeulen, December $200 \mathrm{I}$.

108 "Credit channel and investment behaviour in Austria: a micro-econometric approach" by M. Valderrama, December 2001.

109 "Monetary transmission in Germany: new perspectives on financial constraints and investment spending" by U. von Kalckreuth, December $200 \mathrm{I}$.

110 "Does monetary policy have asymmetric effects? A look at the investment decisions of Italian firms" by E. Gaiotti and A. Generale, December 200 I.

III "Monetary transmission: empirical evidence from Luxembourg firm level data" by P. Lünnemann and T. Mathä, December 200I.

II2 "Firm investment and monetary transmission in the euro area" by J.-B. Chatelain, A. Generale, I. Hernando, U. von Kalckreuth and P. Vermeulen, December 200 I.

$1 / 3$ "Financial frictions and the monetary transmission mechanism: theory, evidence and policy implications" by C. Bean, J. Larsen and K. Nikolov, January 2002.

114 "Monetary transmission in the euro area: where do we stand?" by I. Angeloni, A. Kashyap, B. Mojon, D. Terlizzese, January 2002.

II5 "Monetary policy rules, macroeconomic stability and inflation: a view from the trenches" by A. Orphanides, December 2001.

116 "Rent indices for housing in West Germany 1985 to 1998" by J. Hoffmann and C. Kurz., January 2002.

117 "Hedonic house prices without characteristics: the case of new multiunit housing" by O. Bover and P. Velilla, January 2002.

118 "Durable goods, price indexes and quality change: an application to automobile prices in Italy, 1988-1998" by G. M. Tomat, January 2002.

119 "Monetary policy and the stock market in the euro area" by N. Cassola and C. Morana, January 2002.

120 "Learning stability in economics with heterogenous agents" by S. Honkapohja and K. Mitra, January 2002.

12I "Natural rate doubts" by A. Beyer and R. E. A. Farmer, February 2002.

122 "New technologies and productivity growth in the euro area" by F. Vijselaar and R. Albers, February 2002. 
123 "Analysing and combining multiple credit assessments of financial institutions" by $\mathrm{E}$. Tabakis and A. Vinci, February 2002.

124 "Monetary policy, expectations and commitment" by G. W. Evans and S. Honkapohja, February 2002.

I 25 “Duration, volume and volatility impact of trades” by S. Manganelli, February 2002.

I 26 "Optimal contracts in a dynamic costly state verification model” by C. Monnet and E. Quintin, February 2002.

127 "Performance of monetary policy with internal central bank forecasting" by S. Honkapohja and K. Mitra, February 2002.

128 "Openness, imperfect exchange rate pass-through and monetary policy" by F. Smets and R. Wouters, February 2002.

129 "Non-standard central bank loss functions, skewed risks, and certainty equivalence" by A. al-Nowaihi and L. Stracca, March 2002.

130 "Harmonized indexes of consumer prices: their conceptual foundations" by E. Diewert, March 2002.

I3I "Measurement bias in the HICP: what do we know, and what do we need to know?" by M. A. Wynne and D. Rodríguez-Palenzuela, March 2002.

132 "Inflation dynamics and dual inflation in accession countries: a "new Keynesian" perspective” by O. Arratibel, D. Rodríguez-Palenzuela and C. Thimann, March 2002.

133 "Can confidence indicators be useful to predict short term real GDP growth?" by A. Mourougane and M. Roma, March 2002.

134 "The cost of private transportation in the Netherlands, 1992-1999" by B. Bode and J. Van Dalen, March 2002.

135 "The optimal mix of taxes on money, consumption and income" by F. De Fiore and P. Teles, April 2002.

I36 "Retail bank interest rate pass-through: the new evidence at the euro area level" by G. de Bondt, April 2002.

137 "Equilibrium bidding in the eurosystem's open market operations" by U. Bindseil, April 2002.

138 "New" views on the optimum currency area theory: what is EMU telling us?" by F. P. Mongelli, April 2002.

139 “On currency crises and contagion” by M. Fratzscher, April 2002.

I40 "Price setting and the steady-state effects of inflation" by M. Casares, May 2002.

|4I “Asset prices and fiscal balances” by F. Eschenbach and Ludger Schuknecht, May 2002. 